\title{
Nanostructured Lipid Carriers for Delivery of Chemotherapeutics: A Review
}

\author{
Mohamed Haider ${ }^{1,2, *}$, , Shifaa M. Abdin ${ }^{2}$, Leena Kamal ${ }^{1}$ and Gorka Orive ${ }^{3,4}(\mathbb{D}$ \\ 1 Department of Pharmaceutics and Pharmaceutical Technology, College of Pharmacy, University of Sharjah, \\ Sharjah 27272,UAE; u00042352@sharjah.ac.ae \\ 2 Research Institute of Medical \& Health Sciences, University of Sharjah, Sharjah 27272, UAE; \\ u00044748@sharjah.ac.ae \\ 3 NanoBioCel Group, Laboratory of Pharmaceutics, School of Pharmacy, University of the Basque Country \\ UPV/EHU, Paseo de la Universidad 7, 01006 Vitoria-Gasteiz, Spain; gorka.orive@ehu.es \\ 4 University Institute for Regenerative Medicine and Oral Implantology-UIRMI (UPV/EHU-Fundación \\ Eduardo Anitua), 01006 Vitoria, Spain \\ * Correspondence: mhaider@sharjah.ac.ae; Tel.: +971-65057414; Fax: +971-65585812
}

Received: 10 February 2020; Accepted: 14 March 2020; Published: 23 March 2020

\begin{abstract}
The efficacy of current standard chemotherapy is suboptimal due to the poor solubility and short half-lives of chemotherapeutic agents, as well as their high toxicity and lack of specificity which may result in severe side effects, noncompliance and patient inconvenience. The application of nanotechnology has revolutionized the pharmaceutical industry and attracted increasing attention as a significant means for optimizing the delivery of chemotherapeutic agents and enhancing their efficiency and safety profiles. Nanostructured lipid carriers (NLCs) are lipid-based formulations that have been broadly studied as drug delivery systems. They have a solid matrix at room temperature and are considered superior to many other traditional lipid-based nanocarriers such as nanoemulsions, liposomes and solid lipid nanoparticles (SLNs) due to their enhanced physical stability, improved drug loading capacity, and biocompatibility. This review focuses on the latest advances in the use of NLCs as drug delivery systems and their preparation and characterization techniques with special emphasis on their applications as delivery systems for chemotherapeutic agents and different strategies for their use in tumor targeting.
\end{abstract}

Keywords: nanostructured lipid carriers; chemotherapeutic agents; drug delivery systems; drug targeting; lipid-based nanoparticles

\section{Introduction}

The development of more effective delivery systems for currently available chemotherapeutic agents has recently been the focus of the pharmaceutical industry as high toxicity and/or low efficiency continue to be key obstacles in the management of many types of cancers. Chemotherapeutic agents are limited by their narrow therapeutic window and high risk for toxicity [1]. Therefore, minimizing chemotherapy-induced side effects through selective delivery to tumor sites would increase their efficiency and provide enhanced patient care. Unfortunately, many drug molecules with promising therapeutic potential did not successfully reach clinical trial phases due to the absence of an effective delivery method that can overcome their poor solubility, low bioavailability, large biodistribution, and unacceptable variations in their plasma levels [2].

Nanotechnology has reformed the field of drug delivery and revolutionized medicine. The development of various types of nanoparticles (NPs) that range in size from 10 to $1000 \mathrm{~nm}$ improved the delivery of many drug molecules especially chemotherapeutic agents and provided alternative 
innovative solutions to overcome many of the challenges associated with their safety and efficiency $[3,4]$. NPs possess an array of special features that make them suitable drug carriers. This includes, but is not limited to, their substantial surface-to-volume ratio and significant functional surface that allow them to easily adsorb other compounds [3].

Many types of NPs used as drug carriers are generally, but not necessarily, made of polymers or lipids [5]. A comparison between the two types highly favors the lipid NPs, as they resolved many challenges presented with the polymeric NPs such as cytotoxicity and the lack of suitable methods for large-scale production [6]. The first generation of lipid-based NPs was reported in the early 1990s and is known as SLNs [7] (Figure 1). They were originally developed as a simulation of oil-in-water nanoemulsions where the internal oily phase was substituted by a solid lipid matrix. The development of such system resulted in multiple advantages over the traditional lipid-based formulations, namely liposomes and nanoemulsions, such as avoiding the use of non-aqueous solvents, facilitating the upscaling processes, and improving the protection of labile loaded therapeutic agents conferred by using solid lipids (SL) instead of oily phase in emulsions [8,9]. Nonetheless, SLNs as drug carriers were limited by low drug loading efficiency and increase in the risk of expulsion of the drug from the formulation upon storage due to polymorphic transitions [10]. To overcome those limitations, Müller et al. [10] developed NLCs using mixtures SL and liquid lipids (LL) that form an amorphous solid matrix at both body and room temperature. The incorporation of LL in the matrix is the fundamental step, as it significantly enhanced the properties of the formulation as compared to SLNs. LL contribute to the creation of an amorphous lattice with considerable imperfections in its crystalline solid matrix through which a greater load of the drug can be added in contrast to the perfect crystalline solid matrix formed in SLNs that limited the amount of loaded drug and led to its expulsion due to their limited spatial capacity [2].
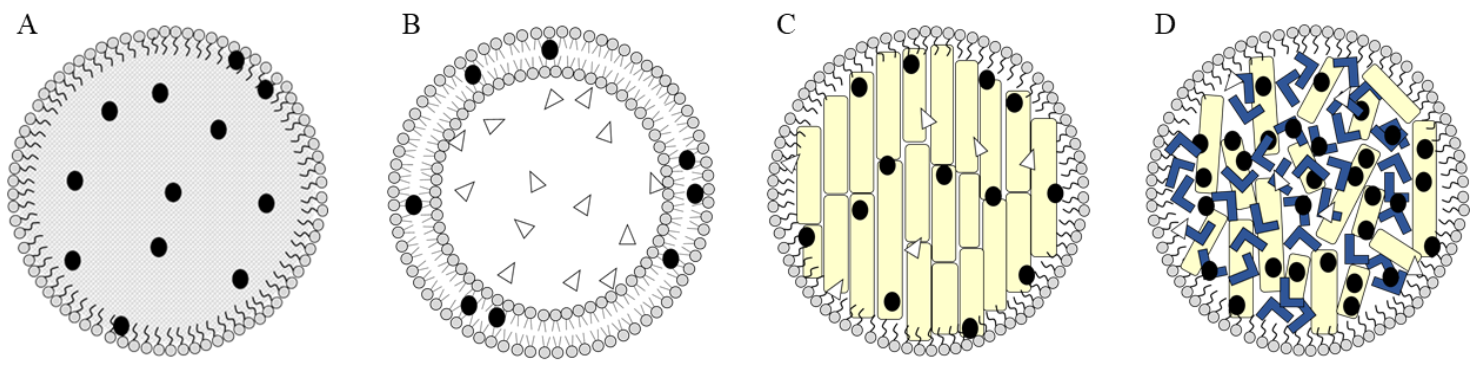

Lipophilic drug molecule
$\triangle$ Hydrophilic drug molecule

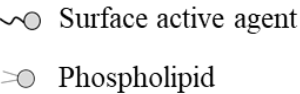

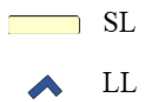

Figure 1. Different types of lipid-based nanoparticles. (A) Nanoemulsions; (B) liposomes; (C) solid lipid nanoparticles (SLNs); and (D) nanostructured lipid carriers (NLCs).

Furthermore, NLCs were able to broaden the spectrum and overcome many of the limitations associated with conventional lipid-based carriers. For instance, having NLCs in solid state at room temperature enhanced their physical stability which is a major barrier in emulsion-based formulae [6]. The availability of suitable methods for large scale production of NLCs resolved the expensive technological requirement for mass production of liposomes [6]. In addition, NLCs are biocompatible systems distinguished by a rigid morphology that contributes to their unique properties compared to other lipid-based formulations [7].

This review focus on the specific use of NLCs in the delivery of chemotherapeutic agents and critically examines their biocompatibility and potential toxicity. The first sections briefly describe the special features of NLCs, the most common methods used for their preparation and characterization with special consideration to the effect of the formulation parameters on the stability and release of chemotherapeutic agents from those lipid-based NPs. This is followed by a comprehensive assessment 
of several significant in vitro and in vivo studies that involved the treatment of a variety of cancers using different types of NLCs as well as the most important targeting strategies used to improve the efficiency of this drug delivery system. Finally, the review highlights the possible toxic effects of NLCs as well as potential means to improve their biocompatibility.

\section{Structure and Classification of NLCs}

NLCs are prepared by mixing spatially incompatible combination of LL and SL in which the oil molecules (i.e., liquid lipid) do not contribute to the crystalline matrix of SL and the crystals of SL do not dissolve in the LL. Nevertheless, this lipid mixture should be homogenous with no phase separation at a temperature below their melting point, i.e., LL should be present as nano-sized compartments within the solid crystalline matrix [11,12].

NLCs can be classified according to the nature of their lipid content and formulation parameters into three different types: imperfect, amorphous, and multiple structure (Figure 2). Imperfect NLCs are obtained by mixing lipids composed of a variety of fatty acids, i.e., with carbon chain of varied length and saturation, which results in frequent crystal lattice imperfections that can accommodate lipid-soluble drug molecules. Accordingly, the drug payload can be further enlarged by increasing imperfections [10]. In the amorphous type, the expulsion of the drug due to crystallization of the lipid matrix is minimized by mixing SL with LL that congeal to an amorphous state (e.g., hydroxyoctacosanyl hydroxystearate or iso-propyl myristate) resulting in a structureless non crystalline matrix [11].

A

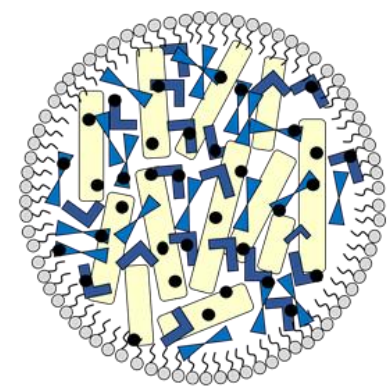

- drug molecule

$\sim \sim$ Liquid lipid
B

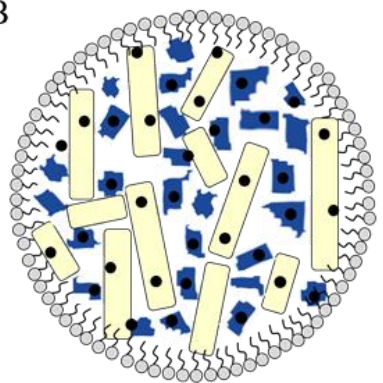

Surface active agent

Amorphous LL

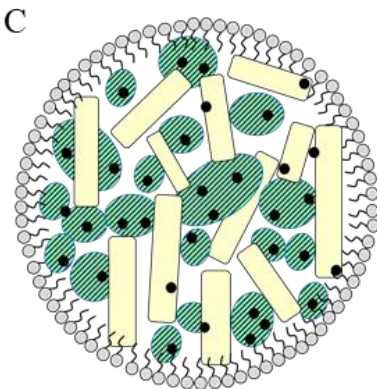

Solid lipid

Oil nano compartments

Figure 2. Different types of NLCs. (A) Imperfect; (B) amorphous; and (C) oil-in-fat-in-water.

Multiple NLCs are oil-in-fat-in-water carriers (O/F/W) composed of a SL matrix enclosing multiple liquid oil nano-compartments. As lipophilic drug molecules are more soluble in LL than SL, the presence of these oil nano-compartments increases the drug loading capacity. In addition, the solid matrix around the nano-compartments acts as a barrier that prevents drug leakage and allows controlled drug release [13]. Multiple type NLCs can be obtained by mixing SL with a large amount of LL using hot homogenization procedure. Upon cooling, oily nano-compartments are formed due to phase separation of excess LL [10-14].

\section{Composition and Methods of Preparation of NLCs}

\subsection{Composition of NLCs}

NLCs are composed of a variety of LL, SL, and surfactants mixed at specific ratios and dispersed in aqueous solutions. When NLCs are used as carriers for chemotherapeutic drug molecules, the selected ingredients should be biocompatible, non-toxic, and suitable for systemic administration [14]. Table 1 enlists examples of SL, LL, and surfactants used in the preparation of NLCs intended for the delivery of anticancer drugs. 
Table 1. Ingredients used in formulation of NLCs.

\begin{tabular}{|c|c|c|}
\hline Type & Name & References \\
\hline \multirow{6}{*}{ Solid lipids } & Glyceryl monostearate & {$[9,15-17]$} \\
\hline & Glyceryl tridecanoate & [18] \\
\hline & Glyceryl tripalmitate & {$[18,19]$} \\
\hline & Glyceryl behenate (Compritol ${ }^{\circledR} 888$ ATO) & [20-23] \\
\hline & Stearic acid & {$[16,24,25]$} \\
\hline & Glyceryl distearate (Precirol ${ }^{\circledR}$ ATO 5) & {$[21,23,26-28]$} \\
\hline \multirow{7}{*}{ Liquid lipids } & Oleic acid & {$[15,17,22,25]$} \\
\hline & Alpha-tocopheryl acetate & [18] \\
\hline & Squalene & {$[21,29]$} \\
\hline & Medium chain triglycerides (MCT)/caprylic and capric triglycerides & {$[20,23]$} \\
\hline & PEG-8 caprylic/capric glycerides (Labrasol ${ }^{\circledR}$ ) & {$[28,30]$} \\
\hline & propylene glycol dicaprylocaprate (Labrafac ${ }^{\mathrm{TM}} \mathrm{PG}$ ) & [30] \\
\hline & Soy lecithin (Epikuron ${ }^{\mathrm{TM}} 200$ ) & [31] \\
\hline \multirow{10}{*}{ Surfactants } & Soybean phosphatidylcholine & {$[18,20]$} \\
\hline & Hydrogenated soybean phosphatidylcholine & [21] \\
\hline & Lecithin & [25] \\
\hline & Solutol ${ }^{\circledR}$ HS 15 (poly-oxyethylene esters of 12 -hydroxystearic acid) & [17] \\
\hline & Soy lecithin (Epikuron ${ }^{\mathrm{TM}} 200$ ) & {$[16,18,32]$} \\
\hline & Pluronic ${ }^{\circledR}$ F-68 (Poloxamer 188) & {$[16,17,27,32]$} \\
\hline & Pluronic F127 (poloxamer 407) & {$[9,23]$} \\
\hline & Tween ${ }^{\circledR} 80$ & {$[19,21,27]$} \\
\hline & Cremophor ${ }^{\circledR}$ RH40 (PEG-40 Hydrogenated Castor Oil) & {$[9,23]$} \\
\hline & Kolliphor ${ }^{\circledR}$ EL (Polyoxyl castor oil) & [9] \\
\hline
\end{tabular}

\subsection{Methods of Preparation of NLCs}

In general, the formulation of NLCs involves the nanoemulsification of a lipohilic phase composed of a mixture of LL and SL (e.g., tripalmitin and squalene, respectively) in an aqueous solution of water-soluble surfactants/emulsifiers [31]. Techniques used in formulation of NLCs include high pressure homogenization (HPH), solvent emulsification/evaporation, microemulsification, ultra-sonification or high-speed homogenization, spray drying and microfluidics technology. The ratio of SL:LL is usually from 70:30 to 99.9:0.1, and the system is stabilized using 0.5-5\% surfactant solutions [33-35].

\subsubsection{High Pressure Homogenization}

The most common methods for the preparation of drug-loaded NLCs are hot HPH and cold HPH (Figure 3). Hot HPH technique involves the dissolution or dispersion of the drug in a mixture of melted LL (e.g., essential digestible oils like Miglyol ${ }^{\circledR} 812$ or soy lecithin) and SL composed of steroids, triglycerides, waxes, or fatty acids, such as glyceryl palmitostearate (Precitol ATO ${ }^{\circledR} 5$ ) and stearic acid. The hot hydrophobic drug mixture is then blended with a heated aqueous solution of hydrophilic and hydrophobic surfactants, such as tween and lecithin respectively, using a high-pressure homogenizer (100-2000 bar) and an average of 3-5 cycles of homogenization. This results in forcing the hydrophobic phase into small cavities in the homogenizer and formation of emulsified particles in the submicron range $[14,31,36,37]$.

This technique is simple and suitable for large scale production. It does not require organic solvents and results in highly stable NPs $[28,33,34,38]$. However, using hot HPH for the preparation of drug-loaded NLCs is limited by the thermolability of the drug as well as the low entrapment efficiency 
and reduced drug loading capacity that may occur due to permeation of the drug molecules into the hydrophilic phase during the crystallization of the lipid phase [14,26].

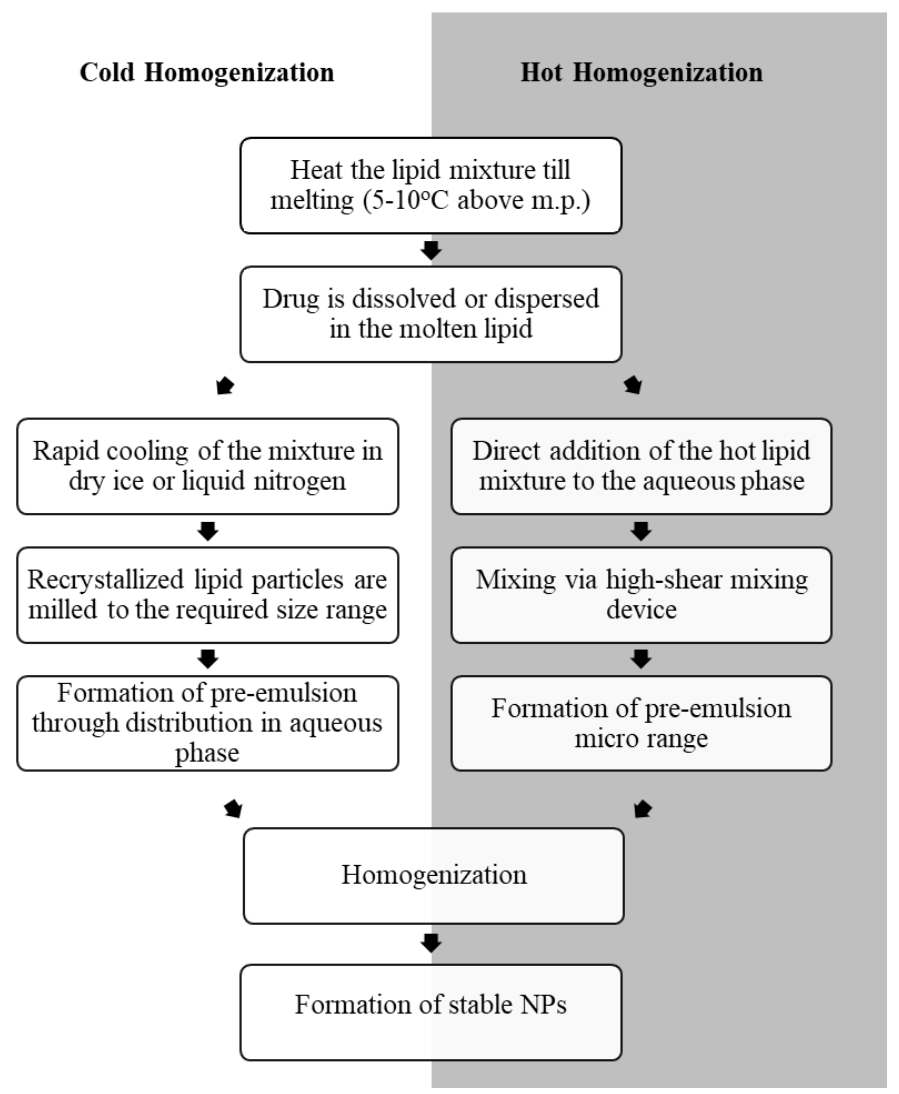

Figure 3. Preparation of NLCs by cold and hot high-shear homogenization.

As a result, cold HPH has emerged as an alternative method for the preparation of drug-loaded NLCs that allowed the encapsulation of thermolabile drugs and increased their drug loading capacity [32]. This technique involves mixing the drug with the lipid phase mixture just above its melting point followed by immediate cooling of the mixture on dry ice or liquid nitrogen which results in rapid recrystallization of SL particles. The particles are then milled down into micron range between 50-100 $\mu \mathrm{m}$ and emulsified in a cold aqueous phase using a high-pressure homogenizer to break the micro particles down into smaller NPs [14,35]. It has to be noted that incomplete homogenization may lead to presence of micro particles that may threaten the quality of mixture distribution [39].

\subsubsection{Solvent Emulsification/Evaporation}

This technique involves the dissolution of the drug and lipid mixture in a water-immiscible organic solvent followed by emulsification in an aqueous phase using ultrasonication or high shear homogenization [24,37]. The organic solution is then kept under low pressure 40-60 mbar till complete evaporation of the organic solvent (Figure 4). This procedure is suitable for the preparation of NLCs containing heat-sensitive drugs as low pressure instead of elevated temperature is used for the removal of the organic solvent and precipitation of the drug-loaded NLCs [2,14,34,40]. However, the process is limited by the presence of residual traces of the organic solvent in the final product which can lead to systemic toxic effects after administration. In addition, this method of preparation may require an extra filtration step, which might not be economically suitable for large scale manufacturers and usually results in a reduction in the percentage yield [2]. 


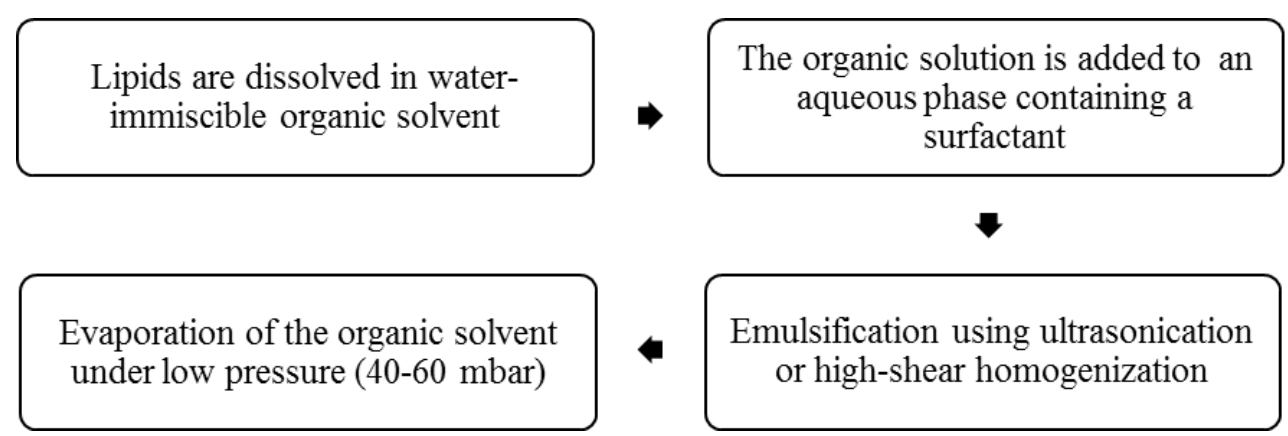

Figure 4. Preparation of NLCs by solvent emulsification/evaporation technique.

\subsubsection{Microemulsions}

This method is one of the most commonly used techniques for the preparation of NLCs due to economic reasons in addition to its simplicity and flexibility for use in formulations of polar and/or non-polar drugs. It involves mixing the melted lipids with a hydrophilic aqueous phase containing a surfactant and a co-surfactant to form an emulsion, either w/o or o/w depending on the proportions used. The emulsion is then vigorously mixed to break the particles down into the micron range. NLCs are then formed by further dispersion of the microemulsion in a chilled hydrophilic phase that causes particles to become smaller [32,41,42]. Although this method can be suitable for the preparation of NLCs loaded with thermolabile drugs, it requires significant amounts of surface active agents and a large volume of water for extensive dilution, which can be considered as the main drawbacks of this technique $[24,34,43,44]$.

\subsubsection{Ultra-Sonication or High-Speed Homogenization}

This method involves direct mixing of the heated lipid phase in the presence of a large proportion of a surfactant in a heated aqueous phase using ultra-sonication or high-speed homogenization $[9,45]$. NLCs obtained using water bath ultra-sonication or high-speed homogenization commonly suffer from large polydispersity and moderate product stability [14,46]. Probe-based sonicators can be more useful to obtain a narrower distribution of the NLCs particle size; however, they are limited by the risk of contamination from the metal of the sonication probe [32]. Nevertheless, the simplicity of the method and the significant availability of ultra-sonicators and high-shear homogenizers in research and production facilities favors this technique over more complex HPH for the preparation of drug-loaded NLCs [35]. This is because HPH depends on exceptionally high levels of pressure (100-200 MPa) and multiple rounds of homogenization for the efficient production of emulsified particles in the target size range, while high speed homogenization only depends on blending at high velocities. Obtaining high pressures for operation is a complex process that requires specific machinery and therefore the method may be more costly than high shear homogenization [35].

\subsubsection{Spray Drying}

The spray drying method is more commonly used for high melting point lipid phases and/or as an alternative approach to lyophilization techniques in the preparation of NLCs [47]. This technique induces particle agglomeration owing to exposure to elevated temperatures and shear stress which results in partial melting of the particles and increase in their kinetic energy giving rise to multiple particle collisions. In order to optimize the yield, it is recommended to utilize SL with melting point higher than $70{ }^{\circ} \mathrm{C}$ at a concentration of $1 \% w / v$ in an aqueous solution of trehalose. The carbohydrate forms a thin protective shell around the particles upon drying and reduces the destabilizing effects of heat and shear during the process [48-50]. Even though spray drying is more economic and efficient than other methods, when it comes to NLCs production, this process is not commonly used due to the 
risk of particle aggregation, possible structural changes of the lipid core and surface surfactant films, and fractional particle degradation due to high temperature used in melting the lipids [51].

\subsubsection{Microfluidics}

Microfluidics have been recently introduced as a novel approach to produce NPs that can optimize their uniformity [52]. In this technique, liquid reagents are forced into a microfluidics chip at precisely controlled flow rates leading to collision and rapid mixing of nanoliter amounts of these reagents under highly controlled pressure [53]. The method was used to prepare Coenzyme Q10-loaded NLCs where a pre-emuslion obtained by mixing cetyl palmitate and Coenzyme Q10 with the aqueous phase using high-speed homogenization was subjected to high pressure microfluidics device followed by cooling and solidification of the formed NLCs at room temperature. This method minimizes polydispersity, reduces production time, and does not involve using organic solvents. Therefore, providing a more favorable approach for large scale production of drug-loaded NLCs over other common methods of preparation [54].

\section{Characterization of Drug Loaded NLCs}

\subsection{Particle Size and Morphology}

The particle size and range of size distribution significantly affect the stability of NLCs. Smaller particles with a limited range of size distribution are more stable and show a lower tendency for aggregation and physical instability during storage. In addition, the size of the particles affects their surface area and hence their solubility and biocompatibility as well as the rate of drug release. The diameter of NLCs generally ranges from 10 to $1000 \mathrm{~nm}$. However, site-specific NLCs, especially those suggested as carriers for chemotherapeutic agents, should have a diameter range of 50-300 nm for increased cellular uptake. On the other hand, the diameter of NLCs intended for intestinal drug delivery ranges above $300 \mathrm{~nm}$ to provide sustained release [55]. Due to the enhanced permeability and retention effect, NLCs loaded with chemotherapeutic agents with size raging between $30 \mathrm{~nm}$ and $100 \mathrm{~nm}$ are extravasated effectively through the leaky neovasculature at tumor sites to deliver the drug load and cleared at much slower rates than larger carriers by the reticulo-endothelial system in the liver and spleen [56,57].

Formulation parameters, such as the quantities and types of lipids, surfactants, and drug added, can significantly affect the particle size and distribution of NLCs. For instance, increasing the amount of LL resulted in larger particles [58]. Similarly, when a low concentration of surfactant is used, larger NLCs particles were obtained when compared to those prepared with high surfactant-to-lipid ratio which had smaller particle size. In contrast, NLCs loaded with a low concentration of the drug had smaller particle size than those containing higher drug concentrations [55].

The shape of NLCs affect their encapsulation efficiency, drug loading, cellular uptake, receptor binding, and targeting potential [59,60]. Studying of surface morphology of drug-loaded NLCs using scanning electron microscopy and transmission electron microscopy (TEM) (Figure 5) showed that NLCs with spherical particles have a lower surface area when compared to anisometric particles which usually requires higher amounts of surfactants for stabilization [61].

\subsection{Surface Charge}

The surface charge can considerably affect the formulation of NLCs as it provides critical information on the aggregation and dispersion of the particles and their long-term stability. The surface charge of NLCs is measured in terms of their zeta potential (ZP) and may vary according to the $\mathrm{pH}$, ionic strength and the type of ions in the surrounding aqueous phase [62]. A greater surface charge is associated with an increase in electrostatic repulsion and less aggregation between the particles. Generally, stable NLCs should have a minimum ZP of $\pm 20 \mathrm{mV}$ [63]. 
Formulation parameters such as concentrations of LL and SL as well as the nature of surfactant significantly affect the surface charge of NLCs. At low LL/SL ratio, using different surfactant resulted in a considerable change in the size and ZP of NLCs, while at a higher LL/SL ratio, the effect was negligible. This is because LL are mostly negatively charged, and hence lipid-based NPs containing a large amount of LL have a net negative charge [9].

Cancer cells have a higher negative surface charge compared to normal cells, which enables preferential electrostatic binding of the cationic NLCs to the negatively charged phospholipids uniquely expressed on the tumor cells [64]. Accordingly, by controlling the charge on the surface of NLCs they can passively target tumor cells. How et al. studied the effect of $\mathrm{pH}$ and drug load on the particle size, ZP, and physical stability of NLCs by incubating tamoxifen-loaded NLCs (TAM-NLC) and drug-free NLCs in $\mathrm{pH} 2.3,6.4,7.4$, and 10.9, which corresponds to the gastric $\mathrm{pH}$, original $\mathrm{pH}$ after preparation in stomach, $\mathrm{pH}$ in blood, and $\mathrm{pH}$ of the deprotonated state of the drug, respectively. The results showed that incubation at $\mathrm{pH} 2.3$ was unfavorable to both drug-free NLCs and TAM-NLC as both formulations exhibited a very low ZP that was accompanied by Ostwald ripening, an increase in particle size, and lower stability. The incubation of TAM-free NLCs at $\mathrm{pH} 10.9$ resulted in an increase in both ZP and stability of the formulations. Interestingly, at $\mathrm{pH} 7.4$, the amount of drug loading had a significant effect on the particle size and ZP of NLCs. When loaded with increasing amounts of TAM, the particle size of the NLCs significantly increased while their surface charge became more positive compared to drug-free NLCs. Those changes were due to the amino group in TAM in association with the increased migration of the drug to the surface of NLCs during formulation, especially at higher concentrations. It was also observed that, even though the ZP of the drug-loaded NLCs at $\mathrm{pH} 6.4$ was higher than that at $\mathrm{pH} 7.4$ they were still relatively unstable, which means that the increase in surface charge of NLCs does not always yield NPs of higher stability [65].

\subsection{Degree of Crystallinity}

The structure of the crystal lattice and the status of its lipid components significantly affect the encapsulation efficiency and the release rate of therapeutic agents from NLCs [66]. In principle, more defects in the crystal lattice profit the encapsulation of drugs [67]. The status of the lipid components can be evaluated using differential scanning calorimetry as different lipids have distinct melting enthalpies and melting points $[39,68]$.

The crystallinity of lipid-based NPs can be significantly affected by the amount of drug loaded, storage time and viscosity of the formulation. Using SL with numerous crystal lattice imperfections can improve the encapsulation of drug as well as its chemical stability in NLCs due to enhanced entrapment and housing of the drug in the lipid matrix $[13,69,70]$.

\subsection{Encapsulation Efficiency Percentage (EE \%)}

After the preparation of drug-loaded NLCs, it is essential to determine the $\%$ of drug encapsulated. This can be determined by measuring the difference between the total drug added and the free non-entrapped drug relative to the total drug added. EE \% significantly affects the release of the drug from NLCs as higher encapsulation alter the concentration gradient and rate of drug release. EE \% values more than $60 \%$ usually indicate the success of the preparation method in loading a proper amount of the drug in the lipid particles $[32,65,71]$.

EE \% of drug-loaded NLCs are affected by formulation parameters such as the nature and concentration of SL and LL. A study on NLCs loading with artemisinin (ART), a lipophilic drug, using increasing amounts of oleic acid as LL, showed EE \% between $59.1 \%$ and $85.3 \%$. Increasing the concentration of LL tends to alter the crystal lattice and increase its imperfections, resulting in a higher $\mathrm{EE} \%$ than those with more regular crystalline structure. Similarly, increasing the amount of SL, such as Compritol ${ }^{\circledR} 888 \mathrm{ATO}$, from 10 to $20 \mathrm{mg}$ showed a remarkable increase in EE \% of ART [72].

The amount of the loaded drug can also have a significant effect on its EE \% in NLCs. For example, in TAM-loaded NLCs an inverse relationship was observed between the EE \% and the amount of drug 
added to the formulation. At low drug concentration, both the interfacial tension at the lipid/water interface and the free energy at the surface of the drug-loaded NLCs remained within the phase boundary of the lipid mixture and the drug. This favored the stabilization of NLCs at a suitable, small particle size and a narrow range of size distribution. However, at higher TAM concentration, the proportion of solid phase during the lipid recrystallization process increased, which resulted in the reduction of $\mathrm{EE} \%$ and compromised the ability of lipid matrix to accommodate more drug [65].

Furthermore, EE \% can be influenced by the nature of the drug where lipophilic drugs usually show high EE \% due to their high affinity to the lipid phase. These drug molecules are homogenously solubilized in the LL/SL mixture and remain entrapped within that lipid system after cooling and formation of rigid lipid particles [32].

\subsection{Stability}

The encapsulation of chemotherapeutic agents in lipid-based NPs improves their chemical and physical stability. NLCs loaded with paclitaxel (PTX) and indocyanine green (ICG) were kept at pH 7.4 for $24 \mathrm{~h}$ under light followed by fluorometric determination of ICG concentration to determine their chemical stability. The results showed that the encapsulated photosensitive ICG remained stable compared to free ICG [15]. However, NLCs are depicted as very dynamic systems due to their large surface area and high surface free energy. Accordingly, the potential of NLCs as carriers for the controlled release of chemotherapeutic agents and other drug molecules is limited by their tendency to aggregate to larger structures upon storage.

Many factors such as storage temperature as well as $\mathrm{pH}$ affect the stability of drug-loaded NLCs. The physical stability of quetrecin-loaded NLCs kept at different temperatures $(4,22$, and $37^{\circ} \mathrm{C}$ ) in absence of light was studied using size, polydispersity index, and ZP as stability indicators. Quetrecin-loaded NLCs were stable at low temperature $\left(4^{\circ} \mathrm{C}\right)$ for 28 days, while higher temperatures of $22{ }^{\circ} \mathrm{C}$ for 10 days and $37^{\circ} \mathrm{C}$ for $24 \mathrm{~h}$ resulted in the occurrence of particle aggregation and decrease in surface charge. This is due to breakage of the hydrogen bonds between the surfactant molecules at the lipid/water interface as a result of increasing temperature [73]. It was also noticed that the ZP of particles stored at $22^{\circ} \mathrm{C}$ was decreased at longer storage duration, which is associated to agglomeration and aggregation of the particles [19].

On the other hand, the effect of $\mathrm{pH}$ on the stability of drug-free and TAM-loaded NLCs stored at room temperature in a dark chamber was investigated by measuring Ostwald's ripening (OR) and optical density (OD) at different time intervals for four weeks. The aggregation of drug-free NLCs was at its highest at $\mathrm{pH} 2.3$ while NLCs loaded with $100 \mathrm{mg}$ and $200 \mathrm{mg}$ TAM had their highest OR at pH 6.4 and 10.9, respectively. Both formulations also showed a significant growth in their particle sizes at pH 7.4 which was not observed with drug-free NLCs. These results indicated that the incorporation of TAM altered the $\mathrm{pH}$ of maximum stability of NLCs [65].

\subsection{Drug Release from NLCs}

The study of the in vitro release of drug molecules from NLCs is a useful tool to predict their performance in vivo. Determination of the cumulative amount of drug released from NLCs is commonly carried out using the dialysis method $[9,74]$. In this procedure, the drug-loaded NLCs are placed inside suitable dialysis bags, immersed in a buffer (e.g., phosphate buffer), and kept at $37^{\circ} \mathrm{C}$ while shaking. Samples of the release buffer are removed at specific time intervals and replaced by an equal volume of fresh buffer solution. Alternatively, Franz diffusion cell can be used to measure in vitro drug release where a cellulose membrane is placed between the donor compartment that contains the drug-loaded NLCs and the receptor compartment containing the release buffer. At specific time points, a sample of the release medium is withdrawn for analysis to determine the amount of drug released. Sink conditions can be sustained by maintaining constant stirring rates and suitable temperature [21].

NLCs loaded with docetaxel (DTX) prolonged the release of drug in vitro, where $77 \%$ of DTX was released at the $96 \mathrm{~h}$ time interval, mainly by dissolution and diffusion, implying that DTX-loaded NLCs 
could retain a constant concentration of the anticancer drug in the body for long time intervals [74]. Similarly, Tryptanthrin-loaded NLCs showed a sustained release pattern with $36-45 \%$ of the drug amount released within $48 \mathrm{~h}$ following zero order release kinetics [21].

Many studies have shown that the release of drug molecules from NLCs usually follows a biphasic pattern characterized by an initial burst release of the loaded drug followed by a phase of sustained drug release [66,75]. For example, the release of Etoposide (ETP) from drug-loaded NLCs occurred at a fast rate over the first $8 \mathrm{~h}$ followed by a period of slow release till an almost complete release of the drug at $36 \mathrm{~h}$ [71] (Figure 5). The initial burst in drug release can be caused by the accumulation of drug in the outer shell of the NLCs due to the phase separation that occurs during lipid crystallization, leading to fast release of the drug from the surface of the particles. In contrast, the sustained release pattern occurs when the drug molecules entrapped in the core of the NPs are slowly released due to the partition between the oil and water phases, diffusion of the drug or erosion of the matrix [10,32]. This biphasic release pattern can be useful in chemotherapy where the initial burst can serve as a primary immediate dose that is followed by a steadier concentration of the drug at the tumor site.

\section{A)}

B)

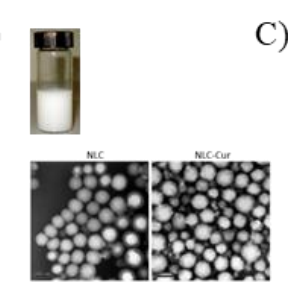

D)

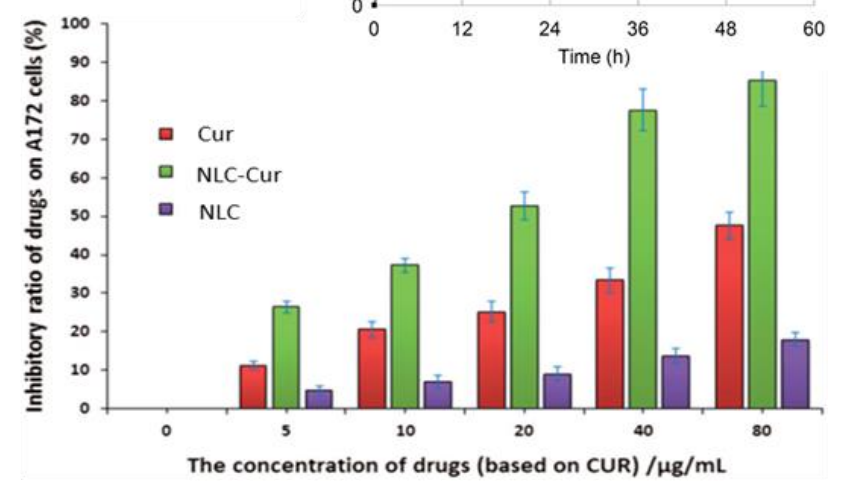

E)

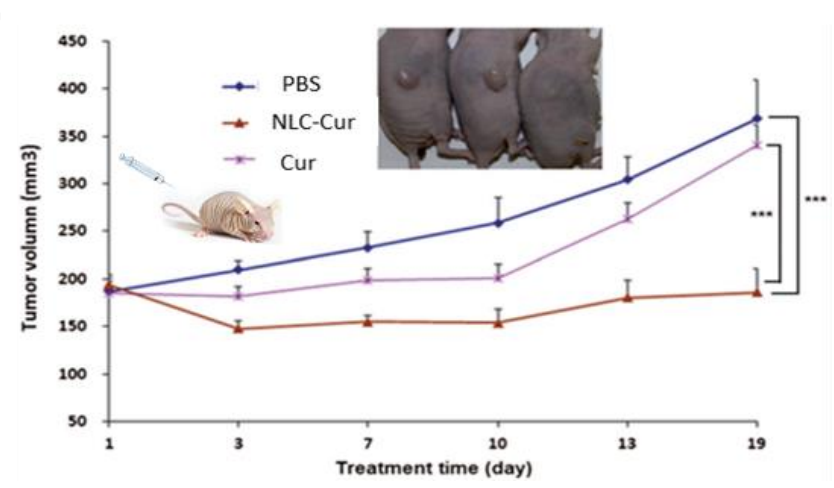

Figure 5. In vitro and in vivo characterization of drug-loaded NLCs. (A) Drug-free NLCs formulation; (B) TEM images showing the spherical nanosize of NLCs and Cur-NLC; (C) in vitro release study showing controlled release of ETP from ETP-loaded NLCs; (D) inhibitory effect of Cur and Cur-NLC on A172 cells (human glioblastoma); and (E) Tumor inhibition effect of Cur, Cur-NLC and phosphate buffer saline (PBS) on nude mice bearing A172 (human glioblastoma) [19,71]. Adapted with permission from Chen et al., 2016 and Jiang et al., 2016, Taylor and Francis. 
The release of drug molecules from NLCs can be controlled by changing the type and concentration of LL, SL and surfactants, and the production conditions. Hydrophobic interaction between the fatty acid chains of the LL and SL affect both rigidity and permeability of NLCs. Lipids with shorter fatty acid chains are more permeable and degrades faster than those with long fatty acids chains resulting in faster release rates. NLCs with small particle size showed faster release of the drug due to their larger surface area and shorter path required for drug diffusion $[6,76]$.

\section{Applications of NLCs in Delivery of Chemotherapeutic Agents}

NLCs were broadly studied as delivery systems for a variety of therapeutic and cosmetic applications due to their well-established biocompatibility and safety profiles. NLCs showed an increasing potential as drug carriers, in particular, by significantly enhancing the encapsulation efficiency for labile hydrophilic and hydrophobic drugs, protecting them from degradation in the body, improving their bioavailability, and controlling their release [77,78]. Table 2 shows examples of NLCs-based formulae for parenteral, topical, oral, ophthalmic, and pulmonary administration for management of central nervous system diseases, inflammatory diseases, skin conditions, bacterial and fungal infection, as well as the administration of local anesthetics [79].

Special attention was given to the use of NLCs as carriers for chemotherapeutic agents due to their ability to enhance the physical and chemical stability of the incorporated drugs and to significantly improve the potential of those therapeutically effective agents revoked due to their poor pharmacokinetic properties $[10,80,81]$. Tables 3 and 4 list several examples for the use of NLCs in delivery and targeting of chemotherapeutic agents showing enhanced $\mathrm{IC}_{50}$ in vitro and tumor inhibition rates in vivo. The use of NLCs as carriers for different chemotherapeutic agents in those studies demonstrates their remarkable ability to boost the therapeutic effect of those drugs across a wide variety of malignancies. This was achieved by loading NLCs with either the chemotherapeutic agents alone, in combination with a low dose of an adjunct, or by conjugating the drug-loaded NLCs with a targeting moiety for active targeting.

Raloxifene hydrochloride (RLX) is a selective estrogen receptor modulator used to lower the risk of breast cancer in post-menopausal women [82]. RLX suffers from low bioavailability, after oral administration, due to poor aqueous solubility and substantial first pass metabolism [83]. RLX-loaded NLCs composed of glyceryl caprylate as LL and glyceryl monostearate as SL (15:85 w:w) and 1\% w/v polyvinyl alcohol (PVA) as stabilizer were prepared and then administered orally to healthy female Wistar rats with weights ranging from 200 to $250 \mathrm{~g}$ using RLX oral suspension as control group. The results showed that using glyceryl caprylate and glyceryl monostearate at that specific ratio to prepare RLX-loaded NLCs enhanced pharmacokinetic parameters of the drug and improved its oral bioavailability. $\mathrm{C}_{\max }$ for RLX-NLC increased $(207.63 \pm 15.81 \mathrm{ng} / \mathrm{mL})$ when compared to that of the drug suspension $(37.88 \pm 3.99 \mathrm{ng} / \mathrm{mL})$. In addition, the AUC representing the degree of absorption was 3.75-fold higher in the drug loaded-NLCs formulations which could be due to the nano-size of the particles and the evasion of the first pass metabolism via lymphatic transport pathway [84].

Nanostructured lipid carriers (NLCs) were also used to improve the poor pharmacokinetic behavior of the incorporated chemotherapeutic agent. Dacarbazine is used in the management of metastatic malignant melanoma, Hodgkin's disease, and soft tissue sarcomas. However, its highly lipophilic nature and short half-life hinder its application. The incorporation of dacarbazine in NLCs resulted in a biphasic drug release whereby $50 \%$ of the drug got released within the first $2 \mathrm{~h}$ while the rest was slowly released for up to $30 \mathrm{~h}$ [85]. Accordingly, with proper dose adjustment, this approach can be used in optimizing the clinical effect of dacarbazine and similar drugs with a half-life of less than one hour after intravenous administration [86].

The lipid nature and minute size of NLCs may also influence the pharmacokinetic properties of the drug as it can alter its distribution and its specific uptake. For example, the therapeutic effect of anticancer drugs used for treatment of brain tumors was enhanced when NLCs were used as carriers due to passive targeting. Curcumin (Cur) is known for its antioxidant and anti-inflammatory effects. 
It is also a promising anti-tumorigenic agent as many studies have shown its significant cytotoxic effect on a variety of human cancer cell lines alone or as adjunct to chemotherapy (Figure 5) [77,87-89]. However, its therapeutic effect is limited by its poor oral bioavailability and rapid elimination [90]. NLCs were used to improve the bioavailability of Cur and increase its deposition in the brain for treatment of brain tumors. To evaluate their effect on the bioavailability and brain targeting of Cur, NLCs composed of tripalmitin and oleic acid (50:50 weight ratio) and 3\% (w/v) polysorbate 80 were injected intraperitoneally in nude mice carrying A172 xenografts and the results were compared to a control group that received an intraperitoneal injection of the free drug [19]. Cur-loaded NLCs (Cur-NLC) showed superior pharmacokinetics parameters where the half-life of the drug was increased from 3.1 to $5.7 \mathrm{~h}$ while the AUC measurements showed a 6.4-fold increase in the drug blood levels in comparison to the control group. Furthermore, the drug biodistribution studies showed a significant deposition of the drug in the brain from Cur-NLC. The study concluded that Cur-NLC enhanced the accumulation of Cur in the brain and tumor and resulted in an increase in the inhibitory effect of Cur from $19.5 \%$ to $82.3 \%$ [19].

Recently, studies were carried out to measure the ability of NLCs to overcome the known problem of multiple drug resistance associated with long-term administration of chemotherapeutic agents. The high loading capacity of NLCs formulation has offered multiple solutions to such problem, as it was possible to collectively incorporate a combination of chemotherapeutic agents in the same NLC particle. This approach can be used not only to control the release of both drugs, but also to enhance their anticancer effect through their integrated influence [91]. For example, Dong et al. prepared NLCs containing a combination of doxorubicin (DOX) and vincristine (VCR) to overcome drug resistance after chemotherapy and the potential for relapses in lymph cancer. The incorporation of both drugs in NLCs resulted in sustaining their release for up to $16 \mathrm{~h}$ and $48 \mathrm{~h}$ for Dox and VCR, respectively. This prolonged release was accompanied by a sustained antitumor effect during tumor progression. DOX-NLC, VCR-NLC, DOX-VCR-NLC, and drug solution were compared in lymph cancer animal model and the results showed that DOX-VCR-NLC exhibited more controlled release with synergistic effects and potent anti-tumor activity which was demonstrated by the inhibition of B-cell lymphoma [91].

Following a similar approach, Wang et al. prepared NLCs loaded with both PTX and DOX for possible synergistic effect in treatment of lung cancer. In vitro cytotoxicity studies on NCL-H460 large cell lung cancer cells showed that $\mathrm{IC}_{50}$ of NLCs loaded with both anticancer agents at PTX/DOX weight ratio of $1 / 1$ was 3 -fold lower than single drug delivery PTX-NLC and DOX-NLC, and nine-fold lower than the free drug formula. In vivo investigation on a non-small cell lung cancer mice model showed that the co-delivery of both chemotherapeutic agents improved the capacity of tumor-targeting and enhanced inhibitory effect of both drugs [22].

Drug-loaded NLCs can also be used as an adjuvant to enhance the therapeutic effect of co-administered anticancer agents. For example, NLCs loaded with melatonin were reported to enhance the effectiveness of TAM in prevention and treatment of breast cancer cells. In this study, melatonin-loaded NLCs were optimized using different types and concentrations of LL, SL and surfactants. The optimum formula was used in combination with a low dose of TAM in treatment of MCF-7 breast cancer cells. The results showed that this treatment inhibited the growth of the cells more effectively than TAM alone by inducing a two-fold increase in the percentage of apoptosis and reducing cell proliferation by $10 \%$ [23]. This progression of cell cycle and apoptosis may be attributed to an increase in endocytosis and release profile in response to the improved uptake of melatonin [92].

The efficiency of NLCs as a carrier for chemotherapeutic agents could be further enhanced by applying surface modifications through the conjugation of targeting moieties such as peptides, folic acid, and antibodies in order to enhance their specificity and selectivity for more effective active targeting of the incorporated drug load. In this way, NLCs can be used for targeting chemotherapeutic agents and restricting their delivery to particular sites in the body to increase their efficiency and reduce their toxicity $[25,93]$. 
Examples of targeted NLCs loaded with chemotherapeutic agents are summarized in Table 4. A linker such as distearoyl phosphatidylethanolamine-polyethylene glycol 2000 (DSPE) functionalized with a proper amino or maleimide functional group was used to conjugate targeting moiety to the surfactant molecules in the aqueous phase. The linker binds to the amino, carboxylic or sulfhydryl groups on the antibody forming a covalent bond that is broken only by a specific enzyme at the target site, ensuring targeted delivery of the drug-loaded NLCs. Transferrin-conjugated PTX-NLCs was characterized to have an EE \% of $91.8 \pm 0.5 \%$ and mean release time of $29.3 \mathrm{~h}$. This formulation showed superior efficacy and cellular uptake for brain tumor over non-targeted NLCs due to transferrin receptor-mediated uptake and demonstrated an increase in cytotoxicity against the U-87 brain cancer cells [94]. Similarly, targeted DTX-loaded NLCs with EE \% of 95-98\% showed more significant antitumor activity than DTX-NLC with $91.2 \%$ inhibition of tumor growth in SKOV3 ovarian cancer cell inoculated mouse model compared to $61.4 \%$ for DTX solution [74,93].

A different targeting approach involved coating PTX-NLC with platelet (PLT) membrane protein. Coating with PLT is an approach usually used to decrease the immune response occurring after administration of drug-loaded lipid-based NPs [95]. This approach also increased the affinity and targeting ability of the drug-loaded NLCs than that of the uncoated NPs toward SKOV3 ovarian cancer cell and maintained the ability of the NLCs to prolong the release of PTX as well [96].

Many studies reported the significant role of NLCs as drug carriers in cancer therapy. However, there are certain challenges that need to be addressed to optimize their therapeutic effect. Most studies focused on investigating the formulation parameters that can yield drug-loaded NLCs with optimum physicochemical properties as the main contributing factor to enhance the delivery of the drug to the target site.

Another limitation is the assumption that the incorporation of a chemotherapeutic agent in NLCs will always empower its cytotoxic effect in vitro and in vivo equally and that studies should only focus on how to maximize this effect. However, this is not always true as it has been shown that the capacity of NLCs loaded with chemotherapeutic agents in demonstrating higher anticancer activity compared to the free drug is of question. For instance, optimized thymoquinone-loaded NLCs exhibited lower anticancer activity compared to free thymoquininone after oral administration in 4T1 mammary carcinoma in mice although animals treated with drug-loaded NLCs showed higher survival rates than those treated with free DOX [97]. These findings suggest that the enhancement of the physiochemical and pharmacokinetic properties by NLCs may not always be accompanied with a higher anticancer activity in vivo. Similar results were reported with transferrin-targeted PTX-NLC where the observed inhibition in U-87 brain cancer cell growth was solely attributed to the conjugation with transferrin while non-targeted PTX-loaded NLCs exhibited a surprising increase in cell viability [94]. This suggests that having prolonged drug release as a feature of drug-loaded NLCs may in fact hinder the needed powerful impact of the chemotherapy for certain tumors where an aggressive therapeutic approach is required. Therefore, careful consideration should be made when designing NLCs to account for the type of cancer, the nature of the drug, the mechanism of delivery, the amount and duration of the burst versus sustained release of the therapeutic agent for optimal therapeutic outcomes. 
Table 2. Applications of NLCs in drug delivery.

\begin{tabular}{|c|c|c|c|}
\hline $\begin{array}{c}\text { Route of } \\
\text { Administration }\end{array}$ & Drug Name & Uses & References \\
\hline \multirow{7}{*}{ Parenteral injection } & Bromocriptine & $\begin{array}{l}\text { Brain targeting for treatment of Parkinson's } \\
\text { disease, neuroleptic malignant syndrome } \\
\text { and pituitary tumors }\end{array}$ & [98] \\
\hline & Apomorphine & $\begin{array}{c}\text { Brain targeting for treatment of Parkinson's } \\
\text { disease }\end{array}$ & {$[99,100]$} \\
\hline & Baicalein & $\begin{array}{l}\text { Brain targeting for prevention or therapy of } \\
\text { ischemic brain damage and } \\
\text { neurodegenerative diseases }\end{array}$ & {$[101,102]$} \\
\hline & Silybin & Hepatotoxicity & {$[103,104]$} \\
\hline & Bifendate & Hepatitis & {$[105,106]$} \\
\hline & Buprenorphine & $\begin{array}{l}\text { Analgesic treatment of chronic pain and } \\
\text { opioid dependence. }\end{array}$ & {$[107,108]$} \\
\hline & Dexamethasone acetate & Anti-inflammatory & [109] \\
\hline \multirow{17}{*}{ Topical } & Cyproterone acetate & Acne vulgaris & [110] \\
\hline & Acitretin & Acne vulgaris and psoriasis & {$[73,111]$} \\
\hline & Psoralen & Psoriasis & {$[29,112]$} \\
\hline & Flurbiprofen & Rheumatoid arthritis, sunburn and gout & {$[113,114]$} \\
\hline & Ketoprofen & Arthritis and skin inflammation & {$[30,115]$} \\
\hline & Celastrol/Indomethacin & Arthritis and inflammatory pain & [116] \\
\hline & Celecoxib & Anti-inflammatory & [43] \\
\hline & Valdecoxib & Anti-inflammatory & [117] \\
\hline & Fluticasone & Atopic dermatitis and psoriasis & [42] \\
\hline & Lidocaine & Local anesthetic & [118] \\
\hline & Benzocaine/Lidocaine & Local anesthetic & [119] \\
\hline & Nanolipid Q 10 CL & Anti-aging/cellular antioxidant & {$[58,120-122]$} \\
\hline & Lutein & $\begin{array}{l}\text { Antioxidant, anti-stress, and blue light filter } \\
\text { protect the skin from photo damage }\end{array}$ & {$[123,124]$} \\
\hline & Meloxicam & Osteoarthritis and rheumatoid arthritis & [125] \\
\hline & Clotrimazole & Antifungal & {$[26,126]$} \\
\hline & Octyl-methoxycinnamate & UVB absorber, Sunscreen & {$[127,128]$} \\
\hline & Donepezil & Alzheimer & [41] \\
\hline \multirow{4}{*}{ Oral } & Repaglinide & Diabetes & [129-131] \\
\hline & Hydrochlorothiazide & Hypertension & [27] \\
\hline & Simvastatin & Antihyperlipidemic & [132] \\
\hline & Lovastatin & Antihyperlipidemic & [133] \\
\hline \multirow{4}{*}{ Ocular } & $\begin{array}{l}\text { Triamcinolone } \\
\text { Acetonide }\end{array}$ & $\begin{array}{l}\text { Inflammatory, edematous, and angiogenic } \\
\text { ocular diseases }\end{array}$ & [134] \\
\hline & Mangiferin & Cataract & [135] \\
\hline & Flurbiprofen & Anti-inflammatory & {$[63,136,137]$} \\
\hline & Moxifloxacin & Treatment of endophthalmitis & [138] \\
\hline \multirow{3}{*}{ Pulmonary } & Itraconazole & Fungal lung infections & [139] \\
\hline & Sildenafil & Pulmonary arterial hypertension & [140] \\
\hline & Montelukast sodium & $\begin{array}{l}\text { Prophylaxis and treatment of chronic } \\
\text { asthma }\end{array}$ & [141] \\
\hline
\end{tabular}


Table 3. Examples of NLCs as carriers for chemotherapeutic agents.

\begin{tabular}{|c|c|c|c|c|c|c|c|c|c|}
\hline \multirow{2}{*}{ Treatment } & \multirow{2}{*}{ Control Drug } & \multirow{2}{*}{ Cancer Type } & \multirow{2}{*}{$\begin{array}{l}\text { In Vitro Cell } \\
\text { Line }\end{array}$} & \multicolumn{3}{|c|}{$\mathrm{IC}_{50}$} & \multicolumn{2}{|c|}{ In Vivo Tumor Inhibition Rate } & \multirow{2}{*}{ References } \\
\hline & & & & Drug-NLCs & Free Drug & Blank NLCs & Drug-NLCs & Free Drug & \\
\hline \multirow{4}{*}{$\begin{array}{l}\text { Docetaxel-NLC } \\
\text { (DTX-NLC) }\end{array}$} & \multirow{4}{*}{$\begin{array}{c}\text { Duopafei } \\
\text { (polymeric micelles } \\
\text { loaded with DTX) }\end{array}$} & Murine melanoma & B16 & $0.47 \mu \mathrm{g} / \mathrm{mL}$ & $0.96 \mu \mathrm{g} / \mathrm{mL}$ & $30.26 \mu \mathrm{g} / \mathrm{mL}$ & $\begin{array}{l}62.69 \%(10 \mathrm{mg} / \mathrm{kg}) \\
90.36 \%(20 \mathrm{mg} / \mathrm{kg})\end{array}$ & $\begin{array}{c}10 \mathrm{mg} / \mathrm{kg}: \\
42.74 \%\end{array}$ & \multirow{4}{*}{ [16] } \\
\hline & & Hepatocellular carcinoma & HepG2 & $0.15 \mu \mathrm{g} / \mathrm{mL}$ & $0.74 \mu \mathrm{g} / \mathrm{mL}$ & $17.50 \mu \mathrm{g} / \mathrm{mL}$ & & & \\
\hline & & Pulmonary adenocarcinoma & A549 & $0.02 \mu \mathrm{g} / \mathrm{mL}$ & $0.08 \mu \mathrm{g} / \mathrm{mL}$ & $10.11 \mu \mathrm{g} / \mathrm{mL}$ & & & \\
\hline & & Ovarian carcinoma & SKOV3 & $0.44 \mu \mathrm{g} / \mathrm{mL}$ & $0.72 \mu \mathrm{g} / \mathrm{mL}$ & $26.34 \mu \mathrm{g} / \mathrm{mL}$ & & & \\
\hline \multirow{5}{*}{$\begin{array}{l}\text { Paclitaxel-NLC } \\
\text { (PTX-NLC) }\end{array}$} & \multirow{5}{*}{ Paclitaxel } & Breast cancer & MCF-7 & $0.075 \mu \mathrm{g} / \mathrm{mL}$ & $0.29 \mu \mathrm{g} / \mathrm{mL}$ & $455.49 \mu \mathrm{g} / \mathrm{mL}$ & & & \multirow{4}{*}{ [17] } \\
\hline & & Multidrug-resistant breast cancer & MCF-7/ADR & $0.065 \mu \mathrm{g} / \mathrm{mL}$ & $8.61 \mu \mathrm{g} / \mathrm{mL}$ & $496.74 \mu \mathrm{g} / \mathrm{mL}$ & & & \\
\hline & & Ovarian carcinoma & SKOV3 & $0.053 \mu \mathrm{g} / \mathrm{mL}$ & $0.16 \mu \mathrm{g} / \mathrm{mL}$ & $487.92 \mu \mathrm{g} / \mathrm{mL}$ & & & \\
\hline & & $\begin{array}{l}\text { Multidrug-resistant ovarian } \\
\text { carcinoma }\end{array}$ & SKOV3-TR30 & $0.1 \mu \mathrm{g} / \mathrm{mL}$ & $9.35 \mu \mathrm{g} / \mathrm{mL}$ & $498.97 \mu \mathrm{g} / \mathrm{mL}$ & & & \\
\hline & & Non-small cell lung carcinoma & $\mathrm{H} 460$ & $0.062 \mu \mathrm{M}$ & $0.193 \mu \mathrm{M}$ & - & $64 \%$ & $26 \%$ & [22] \\
\hline \multirow{5}{*}{$\begin{array}{l}\text { Doxorubicin-NLC } \\
\text { (DOX-NLC) }\end{array}$} & \multirow{5}{*}{ Doxorubicin } & Breast cancer & MCF-7 & $0.15 \mu \mathrm{g} / \mathrm{mL}$ & $0.176 \mu \mathrm{g} / \mathrm{mL}$ & $455.49 \mu \mathrm{g} / \mathrm{mL}$ & & & \multirow{4}{*}{ [17] } \\
\hline & & Multidrug-resistant breast cancer & MCF-7/ADR & $0.83 \mu \mathrm{g} / \mathrm{mL}$ & $6.20 \mu \mathrm{g} / \mathrm{mL}$ & $496.74 \mu \mathrm{g} / \mathrm{mL}$ & & & \\
\hline & & Ovarian carcinoma & SKOV3 & $0.33 \mu \mathrm{g} / \mathrm{mL}$ & $0.52 \mu \mathrm{g} / \mathrm{mL}$ & $487.92 \mu \mathrm{g} / \mathrm{mL}$ & & & \\
\hline & & $\begin{array}{l}\text { Multidrug-resistant ovarian } \\
\text { carcinoma }\end{array}$ & SKOV3-TR30 & $0.52 \mu \mathrm{g} / \mathrm{mL}$ & $1.83 \mu \mathrm{g} / \mathrm{mL}$ & $498.97 \mu \mathrm{g} / \mathrm{mL}$ & & & \\
\hline & & Hairy cell leukemia & HC2 20d2/c & $15.01 \pm 0.5$ & $17.81 \pm 1.2$ & - & & & [25] \\
\hline \multirow{2}{*}{$\begin{array}{l}\text { Quercetin-NLC } \\
\text { (Q-NLC) }\end{array}$} & \multirow{2}{*}{ Quercetin } & \multirow{2}{*}{ Breast cancer } & MCF-7 & $15.8 \mu \mathrm{g} / \mathrm{mL}$ & $>50 \mu \mathrm{g} / \mathrm{mL}$ & $>50 \mu \mathrm{g} / \mathrm{mL}$ & & & \multirow{2}{*}{ [18] } \\
\hline & & & MDA-MB-231 & $14.1 \mu \mathrm{g} / \mathrm{mL}$ & $>50 \mu \mathrm{g} / \mathrm{mL}$ & $>50 \mu \mathrm{g} / \mathrm{mL}$ & & & \\
\hline $\begin{array}{l}\text { Etoposide-NLC } \\
\text { (ETP-NLCs) }\end{array}$ & Etoposide & Gastric cancer & SGC7901 & $6.3 \mu \mathrm{g} / \mathrm{mL}$ & $56.5 \mu \mathrm{g} / \mathrm{mL}$ & - & $\begin{array}{l}\text { Two-fold higher } \\
\text { inhibition than } \\
\text { control }\end{array}$ & & [71] \\
\hline $\begin{array}{l}\text { Cisplatin-NLC } \\
\text { (DDP-NLC) }\end{array}$ & Cisplatin & Head and Neck cancer & $\mathrm{FaDu}$ & $4.7 \mu \mathrm{M}$ & $46.5 \mu \mathrm{M}$ & - & $41.7 \%$ & $9.3 \%$ & [142] \\
\hline $\begin{array}{l}\text { Curcumin-NLC } \\
\text { (CUR-NLC) }\end{array}$ & Curcumin & Brain Cancer & A172 & $20 \mu \mathrm{g} / \mathrm{mL}$ & $80 \mu \mathrm{g} / \mathrm{mL}$ & - & $82.3 \%$ & $19.5 \%$ & [19] \\
\hline \multirow{2}{*}{$\begin{array}{l}\text { Tamoxifen NLC } \\
\text { (TAM-NLC) }\end{array}$} & \multirow{2}{*}{ Tamoxifen } & \multirow{2}{*}{ Breast cancer } & MCF-7 & $5.56 \mu \mathrm{g} / \mathrm{mL}$ & $2.72 \mu \mathrm{g} / \mathrm{mL}$ & - & & & \multirow{2}{*}{ [65] } \\
\hline & & & $4 \mathrm{~T} 1$ & $5.19 \mu \mathrm{g} / \mathrm{mL}$ & $5.13 \mu \mathrm{g} / \mathrm{mL}$ & - & & & \\
\hline
\end{tabular}


Table 4. Examples of targeted-NLCs loaded with chemotherapeutic agents.

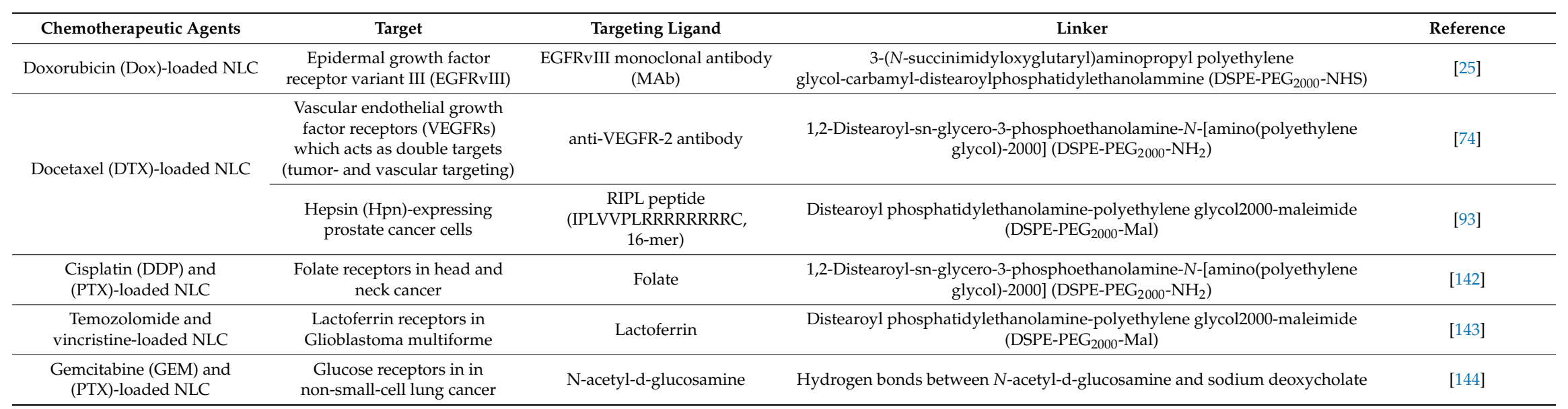




\section{Toxicity and Biocompatibility}

NLCs can be considered as relatively safe colloidal drug carriers as most of the ingredients involved in their preparation are approved for use in pharmaceutical formulations, especially those intended for topical application [145]. However, many lipid-based nanocarriers used for the delivery of chemotherapeutic agents are administered via the parenteral route and they may contain cationic components and linkers for the attachment of ligands for targeting specific sites which can result in an immune response. Like all NPs, the assessment of NLCs toxicity is a multifactorial process that involves testing all the components that make up the backbone of the formulation for their biological compatibility, as well as the effect of the particle size, surface charge and other physicochemical properties on the product safety [145].

In vitro cell viability studies revealed that most cell lines can tolerate up to $1 \mathrm{mg} / \mathrm{mL}$ of lipid doses of drug-free NLCs [146]. Many studies even provided evidence for adequate cellular tolerability for positively charged lipid-based nanocarriers prepared using cationic surfactants such as cetyltrimethylammonium bromide (CTAB). Almeida et al. reported that lipid-based NPs such as SLNs prepared using CTAB showed low toxicity at concentrations over $1 \mathrm{mg} / \mathrm{mL}$ [147]. However, it should be mentioned that certain risks are associated with the use of CTAB as cationic amphiphile in preparation of SLNs as it promotes the release of calcium from neutrophil and induces their damage [148,149]. Hence, careful consideration must be taken when using this cationic agent in the preparation of NLCs. Alternatively, NLCs prepared using other surfactants such as polysorbate 80 and poloxamer 188 showed adequate biocompatibility and low toxicity [150]. However, it was noted that using a mixture of surfactants to improve the stability of the product may increase the risk of toxicity [151].

NLCs also exhibited favorable results when it comes to hemocompatibility and genotoxicity $[37,145,152]$. A hemolysis assay using a combination of glycerol monostearate and polysorbate 80 , a combination frequently used in the preparation of lipid-based NPs, showed only a minor hemolytic effect, even at lipid doses of $1 \mathrm{mg} / \mathrm{mL}$, which places NLCs as one of the promising carriers for parental administration [153].

Nevertheless, one of the drawbacks when it comes to safety of NLCs is the controversial reports about their tendency to induce oxidative stress. Signs of oxidative stress activation such as severe activation of cellular defense mechanism in HepG2 liver cancer cells were observed after treatment with lipid-based NPs prepared using CTAB [154]. Incorporation of an antioxidant active ingredient such as curcumin or using a combination of safe materials such as hard fats and ethoxylated medium chain glycerides resulted in reduction of the risk of oxidative stress [155,156].

Most in vivo studies on using NLCs as drug carriers focused on the determination of pharmacokinetic parameters and biodistribution of the drug after parenteral administration. Only few studies, mainly in rodents, investigated the adverse effects of NLCs on animal health [145]. Most of those studies showed that lipid-based NPs loaded with chemotherapeutics agents are generally safe after dermal, ocular, oral, and parenteral administration, the most common route used for administration of chemotherapeutic agents, and that most of the observed adverse effects after administration were mainly linked to the drug $[2,145,157,158]$. However, some toxic effects, such as neuroinflammation, neurovascular injury, and microglia activation, were reported in mice injected intravenously with SLNs prepared with similar ingredients used in preparation of NLCs [148]. The observed effects were mainly due to the incorporation of cationic ingredients or aggregation of the particles when exposed to an environment with high ionic strength or proteins [159]. The incorporation of polyethylene glycol (PEG) to improve stability of SLNs was also sufficient to prevent the reported inflammatory reaction [149].

In summary, the safety of NLCs varies greatly from one formulation to another. Therefore, deciding whether NLCs can be considered as safe carriers for therapeutic agents must be evaluated on the bases of individual formulae. Future efforts should be directed towards studying the nanotoxicological effects of NLCs and dissecting the proper elements that guarantee their safety. 


\section{Conclusions}

NLCs has revolutionized the field of lipid-based NPs formulation and presented a wide spectrum of advantages over numerous, commonly-used lipophilic preparations. Using NLCs as drug carriers provided a high loading capacity platform for drug delivery by different routes including parenteral, oral, topical, ophthalmic, and pulmonary routes, while enhancing the physical and chemical stability of the drugs, providing flexible control over their release, protecting them against degradation, and improving their poor pharmacokinetic parameters. Having such valuable properties has made NLCs highly favorable for use as carriers for toxic chemotherapeutic agents, taking advantage of their minute particle size and ability to passively or actively target tumor sites to enhance their delivery and relieve the patient from their unwanted side effects. In fact, it is evident from multiple in vitro and in vivo studies that NLCs have managed to optimize the delivery of chemotherapeutic agents, resulting in better safety profiles, higher efficacy, and improved pharmacokinetic properties.

\section{Future Directions}

Most of the research on using NLCs as drug delivery system for chemotherapeutic agents has focused on low molecular weight drugs. Therefore, there is a need to expand the spectrum of their applications to include high molecular weight therapeutics such as peptides, proteins and nucleic acids used in treatment of cancer. This may offer a greater opportunity to manage a wider variety of tumors. In fact, it was reported that NLCs can serve as a novel vector in gene therapy for lung cancer $[160,161]$. In addition, the lack of critical analysis on the safety of NLCs as drug carriers presents another major concern. In fact, only few studies address safety issues affecting the use of NLCs. Therefore, there is a substantial need for more in vivo studies to accurately determine the safety margins and parameters to be embedded as standards for NLCs design.

Finally, the potential of NLCs can be further pursued with more studies on their absorption, distribution, metabolism, and excretion, on methods to upscale their production, and on their application in clinical trials in the near future, where their anticipated results might provide an alternative for a safer and more efficient delivery system for chemotherapeutic agents.

Author Contributions: M.H. and S.M.A. have taken part in conceptualization of the manuscript. M.H. carried out the design, administration and supervision, and acquired the fund for the project. M.H., S.M.A. and L.K. have taken part in data collection, writing the original draft. M.H. and G.O. have taken part in validation, reviewing \& editing of the manuscript. All authors have read and agreed to the published version of the manuscript.

Funding: This research was funded by Aljalila foundation, grant number AJF201777.

Acknowledgments: The authors are grateful to the University of Sharjah Medical Library for providing excellent infrastructure facility for literature review. The authors would also like to appreciate the effort of Farah Afaneh and Layal Kourbaj in gathering some literature data.

Conflicts of Interest: The authors declare no conflict of interest. The funders had no role in the design of the review article; in the collection of data; in the writing of the manuscript, or in the decision to publish the results.

\section{References}

1. Belachew, S.A.; Erku, D.A.; Mekuria, A.B.; Gebresillassie, B.M. Pattern of chemotherapy-related adverse effects among adult cancer patients treated at Gondar University Referral Hospital, Ethiopia: A cross-sectional study. Drug. Healthc. Patient Saf. 2016, 8, 83-90. [CrossRef]

2. Mehnert, W.; Mäder, K. Solid lipid nanoparticles: Production, characterization and applications. Adv. Drug Deliv. Rev. 2001, 47, 165-196. [CrossRef]

3. De Jong, W.H.; Borm, P.J.A. Drug delivery and nanoparticles: Applications and hazards. Int. J. Nanomed. 2008, 3, 133-149. [CrossRef] [PubMed]

4. Shidhaye, S.S.; Vaidya, R.; Sutar, S.; Patwardhan, A.; Kadam, V.J. Solid Lipid Nanoparticles and Nanostructured Lipid Carriers-Innovative Generations of Solid Lipid Carriers. Curr. Drug Deliv. 2008, 5 , 324-331. [CrossRef] [PubMed] 
5. Sawant, K.; Dodiya, S. Recent Advances and Patents on Solid Lipid Nanoparticles. Recent Pat. Drug Deliv. Formul. 2008, 2, 120-135. [CrossRef] [PubMed]

6. Müller, R.H.; Mäder, K.; Gohla, S. Solid lipid nanoparticles (SLN) for controlled drug delivery-A review of the state of the art. Eur. J. Pharm. Biopharm. 2000, 50, 161-177. [CrossRef]

7. Muller, R.H.; Shegokar, R.; Keck, C.M. 20 Years of Lipid Nanoparticles (SLN \& NLC): Present State of Development \& Industrial Applications. Curr. Drug Discov. Technol. 2011, 8, 207-227.

8. Jores, K.; Mehnert, W.; Mäder, K. Physicochemical investigations on solid lipid nanoparticles and on oil-loaded solid lipid nanoparticles: A nuclear magnetic resonance and electron spin resonance study. Pharm. Res. 2003, 20, 1274-1283. [CrossRef] [PubMed]

9. Abdelbary, G.; Haider, M. In vitro characterization and growth inhibition effect of nanostructured lipid carriers for controlled delivery of methotrexate. Pharm. Dev. Technol. 2013, 18, 1159-1168. [CrossRef]

10. Müller, R.H.; Radtke, M.; Wissing, S.A. Nanostructured lipid matrices for improved microencapsulation of drugs. Int. J. Pharm. 2002, 242, 121-128. [CrossRef]

11. Müller, R.H.; Radtke, M.; Wissing, S.A. Solid lipid nanoparticles (SLN) and nanostructured lipid carriers (NLC) in cosmetic and dermatological preparations. Adv. Drug Deliv. Rev. 2002, 54 (Suppl. 1), S131-S155.

12. Kasongo, K.W.; Jansch, M.; Müller, R.H.; Walker, R.B. Evaluation of the in vitro differential protein adsorption patterns of didanosine-loaded nanostructured lipid carriers (NLCs) for potential targeting to the brain. J. Liposome Res. 2011, 21, 245-254. [CrossRef] [PubMed]

13. Jenning, V.; Gohla, S.H. Encapsulation of retinoids in solid lipid nanoparticles (SLN@). J. Microencapsul. 2001, 18, 149-158. [PubMed]

14. Khosa, A.; Reddi, S.; Saha, R.N. Nanostructured lipid carriers for site-specific drug delivery. Biomed. Pharmacother. 2018, 103, 598-613. [CrossRef]

15. Ding, X.; Xu, X.; Zhao, Y.; Zhang, L.; Yu, Y.; Huang, F.; Yin, D.; Huang, H. Tumor targeted nanostructured lipid carrier co-delivering paclitaxel and indocyanine green for laser triggered synergetic therapy of cancer. RSC Adv. 2017, 7, 35086-35095. [CrossRef]

16. Liu, D.; Liu, Z.; Wang, L.; Zhang, C.; Zhang, N. Nanostructured lipid carriers as novel carrier for parenteral delivery of docetaxel. Colloids Surf. B Biointerfaces 2011, 85, 262-269. [CrossRef]

17. Zhang, X.-G.; Miao, J.; Dai, Y.-Q.; Du, Y.-Z.; Yuan, H.; Hu, F.-Q. Reversal activity of nanostructured lipid carriers loading cytotoxic drug in multi-drug resistant cancer cells. Int. J. Pharm. 2008, 361, 239-244. [CrossRef]

18. Sun, M.; Nie, S.; Pan, X.; Zhang, R.; Fan, Z.; Wang, S. Quercetin-nanostructured lipid carriers: Characteristics and anti-breast cancer activities in vitro. Colloids Surf. B Biointerfaces 2014, 113, 15-24. [CrossRef]

19. Chen, Y.; Pan, L.; Jiang, M.; Li, D.; Jin, L. Nanostructured lipid carriers enhance the bioavailability and brain cancer inhibitory efficacy of curcumin both in vitro and in vivo. Drug Deliv. 2016, 23, 1383-1392.

20. Bondì, M.L.; Craparo, E.F.; Giammona, G.; Cervello, M.; Azzolina, A.; Diana, P.; Martorana, A.; Cirrincione, G. Nanostructured Lipid Carriers-Containing Anticancer Compounds: Preparation, Characterization, and Cytotoxicity Studies. Drug Deliv. 2007, 14, 61-67. [CrossRef]

21. Fang, Y.-P.; Lin, Y.-K.; Su, Y.-H.; Fang, J.-Y. Tryptanthrin-Loaded Nanoparticles for Delivery into Cultured Human Breast Cancer Cells, MCF7: The Effects of Solid Lipid/Liquid Lipid Ratios in the Inner Core. Chem. Pharm. Bull. 2011, 59, 266-271. [CrossRef] [PubMed]

22. Wang, Y.; Zhang, H.; Hao, J.; Li, B.; Li, M.; Xiuwen, W. Lung cancer combination therapy: Co-delivery of paclitaxel and doxorubicin by nanostructured lipid carriers for synergistic effect. Drug Deliv. 2016, 23, 1398-1403. [CrossRef]

23. Sabzichi, M.; Samadi, N.; Mohammadian, J.; Hamishehkar, H.; Akbarzadeh, M.; Molavi, O. Sustained release of melatonin: A novel approach in elevating efficacy of tamoxifen in breast cancer treatment. Colloids Surf. B Biointerfaces 2016, 145, 64-71. [CrossRef] [PubMed]

24. Sjöström, B.; Bergenståhl, B. Preparation of submicron drug particles in lecithin-stabilized o w emulsions: I. Model studies of the precipitation of cholesteryl acetate. Int. J. Pharm. 1992, 84, 107-116. [CrossRef]

25. Abdolahpour, S.; Toliyat, T.; Omidfar, K.; Modjtahedi, H.; Wong, A.J.; Rasaee, M.J.; Kashanian, S.; Paknejad, M. Targeted delivery of doxorubicin into tumor cells by nanostructured lipid carriers conjugated to anti-EGFRvIII monoclonal antibody. Artif. Cells Nanomed. Biotechnol. 2018, 46, 89-94. [CrossRef] [PubMed]

26. Souto, E.B.; Müller, R.H. Investigation of the factors influencing the incorporation of clotrimazole in SLN and NLC prepared by hot high-pressure homogenization. J. Microencapsul. 2006, 23, 377-388. [CrossRef] 
27. Cirri, M.; Maestrini, L.; Maestrelli, F.; Mennini, N.; Mura, P.; Ghelardini, C.; Di Cesare Mannelli, L. Design, characterization and in vivo evaluation of nanostructured lipid carriers (NLC) as a new drug delivery system for hydrochlorothiazide oral administration in pediatric therapy. Drug Deliv. 2018, 25, 1910-1921. [CrossRef]

28. Carvajal-Vidal, P.; Fábrega, M.J.; Espina, M.; Calpena, A.C.; García, M.L. Development of Halobetasol-loaded nanostructured lipid carrier for dermal administration: Optimization, physicochemical and biopharmaceutical behavior, and therapeutic efficacy. Nanomed. Nanotechnol. Biol. Med. 2019, 20. [CrossRef]

29. Fang, J.Y.; Fang, C.L.; Liu, C.H.; Su, Y.H. Lipid nanoparticles as vehicles for topical psoralen delivery: Solid lipid nanoparticles (SLN) versus nanostructured lipid carriers (NLC). Eur. J. Pharm. Biopharm. 2008, 70, 633-640. [CrossRef]

30. Cirri, M.; Bragagni, M.; Mennini, N.; Mura, P. Development of a new delivery system consisting in "drugIn cyclodextrin-In nanostructured lipid carriers" for ketoprofen topical delivery. Eur. J. Pharm. Biopharm. 2012, 80, 46-53. [CrossRef]

31. Beloqui, A.; Solinís, M.Á.; Rodríguez-Gascón, A.; Almeida, A.J.; Préat, V. Nanostructured lipid carriers: Promising drug delivery systems for future clinics. Nanomed. Nanotechnol. Biol. Med. 2016, 12, 143-161. [CrossRef] [PubMed]

32. Fang, C.-L.; Al-Suwayeh, S.; Fang, J.-Y. Nanostructured Lipid Carriers (NLCs) for Drug Delivery and Targeting. Recent Pat. Nanotechnol. 2013, 7, 41-55. [CrossRef] [PubMed]

33. Ruktanonchai, U.; Bejrapha, P.; Sakulkhu, U.; Opanasopit, P.; Bunyapraphatsara, N.; Junyaprasert, V.; Puttipipatkhachorn, S. Physicochemical Characteristics, Cytotoxicity, and Antioxidant Activity of Three Lipid Nanoparticulate Formulations of Alpha-lipoic Acid. AAPS PharmSciTech 2009, 10, 227-234. [CrossRef] [PubMed]

34. Iqbal, M.A.; Md, S.; Sahni, J.K.; Baboota, S.; Dang, S.; Ali, J. Nanostructured lipid carriers system: Recent advances in drug delivery. J. Drug Target. 2012, 20, 813-830. [CrossRef]

35. Naseri, N.; Valizadeh, H.; Zakeri-Milani, P. Solid lipid nanoparticles and nanostructured lipid carriers: Structure preparation and application. Adv. Pharm. Bull. 2015, 5, 305-313. [CrossRef]

36. Zhuang, C.Y.; Li, N.; Wang, M.; Zhang, X.N.; Pan, W.S.; Peng, J.J.; Pan, Y.S.; Tang, X. Preparation and characterization of vinpocetine loaded nanostructured lipid carriers (NLC) for improved oral bioavailability. Int. J. Pharm. 2010, 394, 179-185. [CrossRef]

37. Vitorino, C.; Almeida, A.; Sousa, J.; Lamarche, I.; Gobin, P.; Marchand, S.; Couet, W.; Olivier, J.C.; Pais, A. Passive and active strategies for transdermal delivery using co-encapsulating nanostructured lipid carriers: In vitro vs. in vivo studies. Eur. J. Pharm. Biopharm. 2014, 86, 133-144. [CrossRef]

38. Puglia, C.; Santonocito, D.; Ostacolo, C.; Sommella, E.M.; Campiglia, P.; Carbone, C.; Drago, F.; Pignatello, R.; Bucolo, C. Ocular formulation based on palmitoylethanolamide-loaded nanostructured lipid carriers: Technological and pharmacological profile. Nanomaterials 2020, 10, 287. [CrossRef]

39. Bunjes, H.; Westesen, K.; Koch, M.H.J. Crystallization tendency and polymorphic transitions in triglyceride nanoparticles. Int. J. Pharm. 1996, 129, 159-173. [CrossRef]

40. Liu, D.; Jiang, S.; Shen, H.; Qin, S.; Liu, J.; Zhang, Q.; Li, R.; Xu, Q. Diclofenac sodium-loaded solid lipid nanoparticles prepared by emulsion/solvent evaporation method. J. Nanopart. Res. 2011, 13, 2375-2386. [CrossRef]

41. Mendes, I.T.; Ruela, A.L.M.; Carvalho, F.C.; Freitas, J.T.J.; Bonfilio, R.; Pereira, G.R. Development and characterization of nanostructured lipid carrier-based gels for the transdermal delivery of donepezil. Colloids Surf. B Biointerfaces 2019, 177, 274-281. [CrossRef] [PubMed]

42. Doktorovová, S.; Araújo, J.; Garcia, M.L.; Rakovský, E.; Souto, E.B. Formulating fluticasone propionate in novel PEG-containing nanostructured lipid carriers (PEG-NLC). Colloids Surf. B Biointerfaces 2010, 75, 538-542. [CrossRef] [PubMed]

43. Joshi, M.; Patravale, V. Nanostructured lipid carrier (NLC) based gel of celecoxib. Int. J. Pharm. 2008, 346, 124-132. [CrossRef] [PubMed]

44. Xia, Q.; Hao, X.; Lu, Y.; Xu, W.; Wei, H.; Ma, Q.; Gu, N. Production of drug-loaded lipid nanoparticles based on phase behaviors of special hot microemulsions. Colloids Surf. A Physicochem. Eng. Asp. 2008, 313-314, 27-30. [CrossRef]

45. Esposito, E.; Drechsler, M.; Cortesi, R.; Nastruzzi, C. Encapsulation of cannabinoid drugs in nanostructured lipid carriers. Eur. J. Pharm. Biopharm. 2016, 102, 87-91. [CrossRef] 
46. Das, S.; Chaudhury, A. Recent Advances in Lipid Nanoparticle Formulations with Solid Matrix for Oral Drug Delivery. AAPS PharmSciTech 2011, 12, 62-76. [CrossRef]

47. Kaur, P.; Mishra, V.; Shunmugaperumal, T.; Goyal, A.K.; Ghosh, G.; Rath, G. Inhalable spray dried lipidnanoparticles for the co-delivery of paclitaxel and doxorubicin in lung cancer. J. Drug Deliv. Sci. Technol. 2020, 56, 101502. [CrossRef]

48. Freitas, C.; Müller, R.H. Spray-drying of solid lipid nanoparticles (SLN(TM)). Eur. J. Pharm. Biopharm. 1998, 46, 145-151. [CrossRef]

49. Zhang, X.; Pan, W.; Gan, L.; Zhu, C.; Gan, Y.; Nie, S. Preparation of a dispersible PEGylate nanostructured lipid carriers (NLC) loaded with 10-hydroxycamptothecin by spray-drying. Chem. Pharm. Bull. 2008, 56, 1645-1650. [CrossRef]

50. Xia, D.; Shrestha, N.; van de Streek, J.; Mu, H.; Yang, M. Spray drying of fenofibrate loaded nanostructured lipid carriers. Asian J. Pharm. Sci. 2016, 11, 507-515. [CrossRef]

51. Zhong, Q.; Zhang, L. Nanoparticles fabricated from bulk solid lipids: Preparation, properties, and potential food applications. Adv. Colloid Interface Sci. 2019, 273, 102033. [CrossRef] [PubMed]

52. Lababidi, N.; Sigal, V.; Koenneke, A.; Schwarzkopf, K.; Manz, A.; Schneider, M. Microfluidics as tool to prepare size-tunable PLGA nanoparticles with high curcumin encapsulation for efficient mucus penetration. Beilstein J. Nanotechnol. 2019, 10, 2280-2293. [CrossRef] [PubMed]

53. Garg, S.; Heuck, G.; Ip, S.; Ramsay, E. Microfluidics: A transformational tool for nanomedicine development and production. J. Drug Target. 2016, 24, 821-835. [CrossRef] [PubMed]

54. Chen, S.; Liu, W.; Wan, J.; Cheng, X.; Gu, C.; Zhou, H.; Chen, S.; Zhao, X.; Tang, Y.; Yang, X. Preparation of Coenzyme Q10 nanostructured lipid carriers for epidermal targeting with high-pressure microfluidics technique. Drug Dev. Ind. Pharm. 2013, 39, 20-28. [CrossRef] [PubMed]

55. Üner, M. Characterization and imaging of solid lipid nanoparticles and nanostructured lipid carriers. In Handbook of Nanoparticles; Aliofkhazraei, M., Ed.; Springer: New York, NY, USA, 2015; pp. 117-141, ISBN 9783319153384.

56. Peer, D.; Karp, J.M.; Hong, S.; Farokhzad, O.C.; Margalit, R.; Langer, R. Nanocarriers as an emerging platform for cancer therapy. Nat. Nanotechnol. 2007, 2, 751-760. [CrossRef] [PubMed]

57. Danhier, F.; Feron, O.; Préat, V. To exploit the tumor microenvironment: Passive and active tumor targeting of nanocarriers for anti-cancer drug delivery. J. Control. Release 2010, 148, 135-146. [CrossRef]

58. Teeranachaideekul, V.; Souto, E.B.; Junyaprasert, V.B.; Müller, R.H. Cetyl palmitate-based NLC for topical delivery of Coenzyme Q10-Development, physicochemical characterization and in vitro release studies. Eur. J. Pharm. Biopharm. 2007, 67, 141-148. [CrossRef]

59. Moghimi, S.M.; Hunter, A.C.; Andresen, T.L. Factors Controlling Nanoparticle Pharmacokinetics: An Integrated Analysis and Perspective. Annu. Rev. Pharmacol. Toxicol. 2011, 52, 481-503. [CrossRef]

60. Truong, N.P.; Whittaker, M.R.; Mak, C.W.; Davis, T.P. The importance of nanoparticle shape in cancer drug delivery. Expert Opin. Drug Deliv. 2015, 12, 129-142. [CrossRef]

61. Tamjidi, F.; Shahedi, M.; Varshosaz, J.; Nasirpour, A. Nanostructured lipid carriers (NLC): A potential delivery system for bioactive food molecules. Innov. Food Sci. Emerg. Technol. 2013, 19, 29-43. [CrossRef]

62. $\mathrm{Xu}, \mathrm{R}$. Progress in nanoparticles characterization: Sizing and zeta potential measurement. Particuology 2008, 6, 112-115. [CrossRef]

63. Gonzalez-Mira, E.; Egea, M.A.; Souto, E.B.; Calpena, A.C.; García, M.L. Optimizing flurbiprofen-loaded NLC by central composite factorial design for ocular delivery. Nanotechnology 2011, 22, 045101. [CrossRef] [PubMed]

64. Parveen, S.; Sahoo, S.K. Polymeric nanoparticles for cancer therapy. J. Drug Target. 2008, 16, 108-123. [CrossRef] [PubMed]

65. How, C.W.; Rasedee, A.; Manickam, S.; Rosli, R. Tamoxifen-loaded nanostructured lipid carrier as a drug delivery system: Characterization, stability assessment and cytotoxicity. Colloids Surf. B Biointerfaces 2013, 112, 393-399. [CrossRef]

66. Hu, F.Q.; Jiang, S.P.; Du, Y.Z.; Yuan, H.; Ye, Y.Q.; Zeng, S. Preparation and characteristics of monostearin nanostructured lipid carriers. Int. J. Pharm. 2006, 314, 83-89. [CrossRef]

67. Han, F.; Li, S.; Yin, R.; Liu, H.; Xu, L. Effect of surfactants on the formation and characterization of a new type of colloidal drug delivery system: Nanostructured lipid carriers. Colloids Surf. A Physicochem. Eng. Asp. 2008, 315, 210-216. [CrossRef] 
68. Sanjula, B.; Shah, F.M.; Javed, A.; Alka, A. Effect of poloxamer 188 on lymphatic uptake of carvedilol-loaded solid lipid nanoparticles for bioavailability enhancement. J. Drug Target. 2009, 17, 249-256. [CrossRef]

69. Jenning, V.; Gohla, S. Comparison of wax and glyceride solid lipid nanoparticles (SLN@). Int. J. Pharm. 2000, 196, 219-222. [CrossRef]

70. Teeranachaideekul, V.; Müller, R.H.; Junyaprasert, V.B. Encapsulation of ascorbyl palmitate in nanostructured lipid carriers (NLC)-Effects of formulation parameters on physicochemical stability. Int. J. Pharm. 2007, 340, 198-206. [CrossRef]

71. Jiang, H.; Pei, L.; Liu, N.; Li, J.; Li, Z.; Zhang, S. Etoposide-loaded nanostructured lipid carriers for gastric cancer therapy. Drug Deliv. 2016, 23, 1379-1382. [CrossRef]

72. Emami, J.; Yousefian, H.; Sadeghi, H. Targeted nanostructured lipid carrier for brain delivery of artemisinin: Design, preparation, characterization, optimization and cell toxicity. J. Pharm. Pharm. Sci. 2018, 21, 225s-241s. [CrossRef] [PubMed]

73. Sue Lee, C.; Koo, J. A review of acitretin, a systemic retinoid for the treatment of psoriasis. Expert Opin. Pharmacother. 2005, 6, 1725-1734. [CrossRef] [PubMed]

74. Liu, D.; Liu, F.; Liu, Z.; Wang, L.; Zhang, N. Tumor specific delivery and therapy by double-targeted nanostructured lipid carriers with anti-VEGFR-2 antibody. Mol. Pharm. 2011, 8, 2291-2301. [CrossRef] [PubMed]

75. Castelli, F.; Puglia, C.; Sarpietro, M.G.; Rizza, L.; Bonina, F. Characterization of indomethacin-loaded lipid nanoparticles by differential scanning calorimetry. Int. J. Pharm. 2005, 304, 231-238. [CrossRef] [PubMed]

76. Zur Mühlen, A.; Schwarz, C.; Mehnert, W. Solid lipid nanoparticles (SLN) for controlled drug delivery-Drug release and release mechanism. Eur. J. Pharm. Biopharm. 1998, 45, 149-155. [CrossRef]

77. El-Bahr, S.M. Effect of curcumin on hepatic antioxidant enzymes activities and gene expressions in rats intoxicated with aflatoxin B1. Phyther. Res. 2015, 29, 134-140. [CrossRef]

78. Talegaonkar, S.; Bhattacharyya, A. Potential of Lipid Nanoparticles (SLNs and NLCs) in Enhancing Oral Bioavailability of Drugs with Poor Intestinal Permeability. AAPS PharmSciTech 2019, 20, 121. [CrossRef]

79. Jansook, P.; Fülöp, Z.; Ritthidej, G.C. Amphotericin B loaded solid lipid nanoparticles (SLNs) and nanostructured lipid carrier (NLCs): Physicochemical and solid-solution state characterizations. Drug Dev. Ind. Pharm. 2019, 45, 560-567. [CrossRef]

80. Müller, R.H.; Petersen, R.D.; Hommoss, A.; Pardeike, J. Nanostructured lipid carriers (NLC) in cosmetic dermal products. Adv. Drug Deliv. Rev. 2007, 59, 522-530. [CrossRef]

81. Tikekar, R.V.; Nitin, N. Distribution of Encapsulated Materials in Colloidal Particles and Its Impact on Oxidative Stability of Encapsulated Materials. Langmuir 2012, 28, 9233-9243. [CrossRef]

82. Riggs, B.L.; Hartmann, L.C. Selective estrogen-receptor modulators-Mechanisms of action and application to clinical practice. N. Engl. J. Med. 2003, 348, 1192. [CrossRef] [PubMed]

83. Patil, P.H.; Belgamwar, V.S.; Patil, P.R.; Surana, S.J. Solubility Enhancement of Raloxifene Using Inclusion Complexes and Cogrinding Method. J. Pharm. 2013, 2013, 527380. [CrossRef] [PubMed]

84. Shah, N.V.; Seth, A.K.; Balaraman, R.; Aundhia, C.J.; Maheshwari, R.A.; Parmar, G.R. Nanostructured lipid carriers for oral bioavailability enhancement of raloxifene: Design and in vivo study. J. Adv. Res. 2016, 7, 423-434. [CrossRef] [PubMed]

85. Almousallam, M.; Moia, C.; Zhu, H. Development of nanostructured lipid carrier for dacarbazine delivery. Int. Nano Lett. 2015, 5, 241-248. [CrossRef]

86. Breithaupt, H.; Dammann, A.; Aigner, K. Pharmacokinetics of dacarbazine (DTIC) and its metabolite 5-aminoimidazole-4-carboxamide (AIC) following different dose schedules. Cancer Chemother. Pharmacol. 1982, 9, 103-109. [CrossRef]

87. Jia, T.; Zhang, L.; Duan, Y.; Zhang, M.; Wang, G.; Zhang, J.; Zhao, Z. The differential susceptibilities of MCF-7 and MDA-MB-231 cells to the cytotoxic effects of curcumin are associated with the PI3K/Akt-SKP2- Cip/Kips pathway. Cancer Cell Int. 2014, 14, 126. [CrossRef]

88. Vecchi Brumatti, L.; Marcuzzi, A.; Tricarico, M.P.; Zanin, V.; Girardelli, M.; Bianco, M.A. Curcumin and Inflammatory Bowel Disease: Potential and Limits of Innovative Treatments. Molecules 2014, 19, 21127-21153. [CrossRef]

89. Chen, Q.Y.; Jiao, D.M.; Wang, L.F.; Wang, L.; Hu, H.Z.; Song, J.; Yan, J.; Wu, L.J.; Shi, J.G. Curcumin inhibits proliferation-migration of NSCLC by steering crosstalk between a Wnt signaling pathway and an adherens junction via EGR-1. Mol. Biosyst. 2015, 11, 859-868. [CrossRef] 
90. Park, W.; Ruhul Amin, A.R.M.; Chen, Z.G.; Shin, D.M. New perspectives of curcumin in cancer prevention. Cancer Prev. Res. 2013, 6, 387-400. [CrossRef]

91. Dong, X.; Wang, W.; Qu, H.; Han, D.; Zheng, J.; Sun, G. Targeted delivery of doxorubicin and vincristine to lymph cancer: Evaluation of novel nanostructured lipid carriers in vitro and in vivo. Drug Deliv. 2016, 23, 1374-1378. [CrossRef]

92. Huang, Y.; He, L.; Liu, W.; Fan, C.; Zheng, W.; Wong, Y.-S.; Chen, T. Selective cellular uptake and induction of apoptosis of cancer-targeted selenium nanoparticles. Biomaterials 2013, 34, 7106-7116. [CrossRef] [PubMed]

93. Lee, S.G.; Kim, C.H.; Sung, S.W.; Lee, E.S.; Goh, M.S.; Yoon, H.Y.; Kang, M.J.; Lee, S.; Choi, Y.W. RIPL peptide-conjugated nanostructured lipid carriers for enhanced intracellular drug delivery to hepsin-expressing cancer cells. Int. J. Nanomed. 2018, 13, 3263-3278. [CrossRef] [PubMed]

94. Emami, J.; Rezazadeh, M.; Sadeghi, H.; Khadivar, K. Development and optimization of transferrin-conjugated nanostructured lipid carriers for brain delivery of paclitaxel using Box-Behnken design. Pharm. Dev. Technol. 2017, 22, 370-382. [CrossRef] [PubMed]

95. Hu, C.M.J.; Fang, R.H.; Wang, K.C.; Luk, B.T.; Thamphiwatana, S.; Dehaini, D.; Nguyen, P.; Angsantikul, P.; Wen, C.H.; Kroll, A.V.; et al. Nanoparticle biointerfacing by platelet membrane cloaking. Nature 2015, 526, 118-121. [CrossRef] [PubMed]

96. Bang, K.H.; Na, Y.G.; Huh, H.W.; Hwang, S.J.; Kim, M.S.; Kim, M.; Lee, H.K.; Cho, C.W. The delivery strategy of paclitaxel nanostructured lipid carrier coated with platelet membrane. Cancers 2019, 11, 807. [CrossRef] [PubMed]

97. Ong, Y.S.; Yazan, L.S.; Ng, W.K.; Abdullah, R.; Mustapha, N.M.; Sapuan, S.; Foo, J.B.; Tor, Y.S.; How, C.W.; Rahman, N.A.; et al. Thymoquinone loaded in nanostructured lipid carrier showed enhanced anticancer activity in 4 T1 tumor-bearing mice. Nanomedicine 2018, 13, 1567-1582. [CrossRef]

98. Esposito, E.; Mariani, P.; Ravani, L.; Contado, C.; Volta, M.; Bido, S.; Drechsler, M.; Mazzoni, S.; Menegatti, E.; Morari, M.; et al. Nanoparticulate lipid dispersions for bromocriptine delivery: Characterization and in vivo study. Eur. J. Pharm. Biopharm. 2012, 80, 306-314. [CrossRef]

99. Subramony, J.A. Apomorphine in dopaminergic therapy. Mol. Pharm. 2006, 3, 380-385. [CrossRef]

100. Hsu, S.H.; Wen, C.J.; Al-Suwayeh, S.A.; Chang, H.W.; Yen, T.C.; Fang, J.Y. Physicochemical characterization and in vivo bioluminescence imaging of nanostructured lipid carriers for targeting the brain: Apomorphine as a model drug. Nanotechnology 2010, 21, 405101. [CrossRef]

101. Mu, X.; He, G.R.; Yuan, X.; Li, X.X.; Du, G.H. Baicalein protects the brain against neuron impairments induced by MPTP in C57BL/6 mice. Pharmacol. Biochem. Behav. 2011, 98, 286-291. [CrossRef]

102. Tsai, M.J.; Wu, P.C.; Huang, Y.B.; Chang, J.S.; Lin, C.L.; Tsai, Y.H.; Fang, J.Y. Baicalein loaded in tocol nanostructured lipid carriers (tocol NLCs) for enhanced stability and brain targeting. Int. J. Pharm. 2012, 423, 461-470. [CrossRef]

103. Gazak, R.; Walterova, D.; Kren, V. Silybin and Silymarin-New and Emerging Applications in Medicine. Curr. Med. Chem. 2007, 14, 315-338. [CrossRef]

104. Jia, L.; Zhang, D.; Li, Z.; Duan, C.; Wang, Y.; Feng, F.; Wang, F.; Liu, Y.; Zhang, Q. Nanostructured lipid carriers for parenteral delivery of silybin: Biodistribution and pharmacokinetic studies. Colloids Surf. B Biointerfaces 2010, 80, 213-218. [CrossRef]

105. Pan, S.-Y.; Yang, R.; Dong, H.; Yu, Z.; Ko, K.-M. Bifendate treatment attenuates hepatic steatosis in cholesterol/bile salt- and high-fat diet-induced hypercholesterolemia in mice. Eur. J. Pharmacol. 2006, 552, 170-175. [CrossRef]

106. Feng, F.; Zheng, D.; Zhang, D.; Duan, C.; Wang, Y.; Jia, L.; Wang, F.; Liu, Y.; Gao, Q.; Zhang, Q. Preparation, characterization and biodistribution of nanostructured lipid carriers for parenteral delivery of bifendate. $J$. Microencapsul. 2011, 28, 280-285. [CrossRef]

107. Ohtani, M. Basic pharmacology of buprenorphine. Eur. J. Pain Suppl. 2007, 1, 69-73. [CrossRef]

108. Wang, J.J.; Liu, K.S.; Sung, K.C.; Tsai, C.Y.; Fang, J.Y. Lipid nanoparticles with different oil/fatty ester ratios as carriers of buprenorphine and its prodrugs for injection. Eur. J. Pharm. Sci. 2009, 38, 138-146. [CrossRef]

109. Xu, X.; Zhao, C.; Yang, H.; Jian, Y.; Zhang, Z.; Huang, Y. Anti-inflammatory activity of injectable dexamethasone acetate-loaded nanostructured lipid carriers. Drug Deliv. 2011, 18, 485-492. [CrossRef]

110. Štecová, J.; Mehnert, W.; Blaschke, T.; Kleuser, B.; Sivaramakrishnan, R.; Zouboulis, C.C.; Seltmann, H.; Korting, H.C.; Kramer, K.D.; Schäfer-Korting, M. Cyproterone acetate loading to lipid nanoparticles for topical acne treatment: Particle characterisation and skin uptake. Pharm. Res. 2007, 24, 991-1000. [CrossRef] 
111. Agrawal, Y.; Petkar, K.C.; Sawant, K.K. Development, evaluation and clinical studies of Acitretin loaded nanostructured lipid carriers for topical treatment of psoriasis. Int. J. Pharm. 2010, 401, 93-102. [CrossRef]

112. Stern, R.S. Psoralen and Ultraviolet A Light Therapy for Psoriasis. N. Engl. J. Med. 2007, 357, 682. [CrossRef]

113. González-Mira, E.; Nikolić, S.; García, M.L.; Egea, M.A.; Souto, E.B.; Calpena, A.C. Potential use of nanostructured lipid carriers for topical delivery of flurbiprofen. J. Pharm. Sci. 2011, 100, 242-251. [CrossRef]

114. Han, F.; Li, S.; Yin, R.; Shi, X.; Jia, Q. Investigation of nanostructured lipid carriers for transdermal delivery of flurbiprofen. Drug Dev. Ind. Pharm. 2008, 34, 453-458. [CrossRef]

115. Sütő, B.; Berkó, S.; Kozma, G.; Kukovecz, Á.; Budai-Szucs, M.; Erös, G.; Kemény, L.; Sztojkov-Ivanov, A.; Gáspár, R.; Csányi, E. Development of ibuprofen-loaded nanostructured lipid carrier-based gels: Characterization and investigation of in vitro and in vivo penetration through the skin. Int. J. Nanomed. 2016, 11, 1201-1212.

116. Kang, Q.; Liu, J.; Zhao, Y.; Liu, X.; Liu, X.-Y.; Wang, Y.-J.; Mo, N.-L.; Wu, Q. Transdermal delivery system of nanostructured lipid carriers loaded with Celastrol and Indomethacin: Optimization, characterization and efficacy evaluation for rheumatoid arthritis. Artif. Cells, Nanomed. Biotechnol. 2018, 46, S585-S597. [CrossRef]

117. Joshi, M.; Patravale, V. Formulation and Evaluation of Nanostructured Lipid Carrier (NLC)-based Gel of Valdecoxib. Drug Dev. Ind. Pharm. 2006, 32, 911-918. [CrossRef]

118. Pathak, P.; Nagarsenker, M. Formulation and Evaluation of Lidocaine Lipid Nanosystems for Dermal Delivery. AAPS PharmSciTech 2009, 10, 985-992. [CrossRef]

119. Puglia, C.; Sarpietro, M.G.; Bonina, F.; Castelli, F.; Zammataro, M.; Chiechio, S. Development, characterization, and in vitro and in vivo evaluation of benzocaine- and lidocaine-loaded nanostructrured lipid carriers. J. Pharm. Sci. 2011, 100, 1892-1899. [CrossRef]

120. Junyaprasert, V.B.; Teeranachaideekul, V.; Souto, E.B.; Boonme, P.; Müller, R.H. Q10-loaded NLC versus nanoemulsions: Stability, rheology and in vitro skin permeation. Int. J. Pharm. 2009, 377, 207-214. [CrossRef]

121. Graf, J. Antioxidants and skin care: The essentials. Plast. Reconstr. Surg. 2010, 125, 378-383. [CrossRef]

122. Pardeike, J.; Schwabe, K.; Müller, R.H. Influence of nanostructured lipid carriers (NLC) on the physical properties of the Cutanova Nanorepair Q10 cream and the in vivo skin hydration effect. Int. J. Pharm. 2010, 396, 166-173. [CrossRef] [PubMed]

123. Roberts, R.L.; Green, J.; Lewis, B. Lutein and zeaxanthin in eye and skin health. Clin. Dermatol. 2009, 27, 195-201. [CrossRef] [PubMed]

124. Mitri, K.; Shegokar, R.; Gohla, S.; Anselmi, C.; Müller, R.H. Lipid nanocarriers for dermal delivery of lutein: Preparation, characterization, stability and performance. Int. J. Pharm. 2011, 414, 267-275. [CrossRef] [PubMed]

125. Khalil, R.M.; Abd-Elbary, A.; Kassem, M.A.; Ghorab, M.M.; Basha, M. Nanostructured lipid carriers (NLCs) versus solid lipid nanoparticles (SLNs) for topical delivery of meloxicam. Pharm. Dev. Technol. 2014, 19, 304-314. [CrossRef]

126. Souto, E.B.; Wissing, S.A.; Barbosa, C.M.; Müller, R.H. Development of a controlled release formulation based on SLN and NLC for topical clotrimazole delivery. Int. J. Pharm. 2004, 278, 71-77. [CrossRef]

127. Nikolić, S.; Keck, C.M.; Anselmi, C.; Müller, R.H. Skin photoprotection improvement: Synergistic interaction between lipid nanoparticles and organic UV filters. Int. J. Pharm. 2011, 414, 276-284. [CrossRef]

128. Puglia, C.; Bonina, F.; Rizza, L.; Blasi, P.; Schoubben, A.; Perrotta, R.; Tarico, M.S.; Damiani, E. Lipid nanoparticles as carrier for octyl-methoxycinnamate: In vitro percutaneous absorption and photostability studies. J. Pharm. Sci. 2012, 101, 301-311. [CrossRef]

129. Jain, S.K.; Agrawal, G.P.; Jain, N.K. A novel calcium silicate based microspheres of repaglinide: In vivo investigations. J. Control. Release 2006, 113, 111-116. [CrossRef]

130. Qi, S.; Marchaud, D.; Craig, D.Q.M. An investigation into the mechanism of dissolution rate enhancement of poorly water-soluble drugs from spray chilled gelucire 50/13 microspheres. J. Pharm. Sci. 2010, 99, 262-274. [CrossRef]

131. Date, A.A.; Vador, N.; Jagtap, A.; Nagarsenker, M.S. Lipid nanocarriers (GeluPearl) containing amphiphilic lipid Gelucire 50/13 as a novel stabilizer: Fabrication, characterization and evaluation for oral drug delivery. Nanotechnology 2011, 22, 275102. [CrossRef]

132. Fathi, H.A.; Allam, A.; Elsabahy, M.; Fetih, G.; El-Badry, M. Nanostructured lipid carriers for improved oral delivery and prolonged antihyperlipidemic effect of simvastatin. Colloids Surf. B Biointerfaces 2018, 162, 236-245. [CrossRef] 
133. Chen, C.C.; Tsai, T.H.; Huang, Z.R.; Fang, J.Y. Effects of lipophilic emulsifiers on the oral administration of lovastatin from nanostructured lipid carriers: Physicochemical characterization and pharmacokinetics. Eur. J. Pharm. Biopharm. 2010, 74, 474-482. [CrossRef]

134. Araújo, J.; Nikolic, S.; Egea, M.A.; Souto, E.B.; Garcia, M.L. Nanostructured lipid carriers for triamcinolone acetonide delivery to the posterior segment of the eye. Colloids Surf. B Biointerfaces 2011, 88, 150-157. [CrossRef]

135. Liu, R.; Liu, Z.; Zhang, C.; Zhang, B. Nanostructured lipid carriers as novel ophthalmic delivery system for mangiferin: Improving in vivo ocular bioavailability. J. Pharm. Sci. 2012, 101, 3833-3844. [CrossRef]

136. Gonzalez-Mira, E.; Sa, S.; C, N.; Calpena, A.C.; Egea, M.A.; Souto, E.B.; Luisa, M.; Ia, G. Improved and Safe Transcorneal Delivery of Flurbiprofen by NLC and NLC-Based Hydrogels. J. Pharm. Sci. 2011, 101, 707-725. [CrossRef]

137. Tian, B.; Luo, Q.; Song, S.; Liu, D.; Pan, H.; Zhang, W.; He, L.; Ma, S.; Yang, X.; Pan, W. Novel surface-modified nanostructured lipid carriers with partially deacetylated water-soluble chitosan for efficient ocular delivery. J. Pharm. Sci. 2012, 101, 1040-1049. [CrossRef]

138. Gade, S.; Patel, K.K.; Gupta, C.; Anjum, M.M.; Deepika, D.; Agrawal, A.K.; Singh, S. An Ex Vivo Evaluation of Moxifloxacin Nanostructured Lipid Carrier Enriched In Situ Gel for Transcorneal Permeation on Goat Cornea. J. Pharm. Sci. 2019, 108, 2905-2916. [CrossRef]

139. Pardeike, J.; Weber, S.; Haber, T.; Wagner, J.; Zarfl, H.P.; Plank, H.; Zimmer, A. Development of an Itraconazole-loaded nanostructured lipid carrier (NLC) formulation for pulmonary application. Int. J. Pharm. 2011, 419, 329-338. [CrossRef]

140. Nafee, N.; Makled, S.; Boraie, N. Nanostructured lipid carriers versus solid lipid nanoparticles for the potential treatment of pulmonary hypertension via nebulization. Eur. J. Pharm. Sci. 2018, 125, 151-162. [CrossRef]

141. Patil-Gadhe, A.; Kyadarkunte, A.; Patole, M.; Pokharkar, V. Montelukast-loaded nanostructured lipid carriers: Part II Pulmonary drug delivery and in vitro-in vivo aerosol performance. Eur. J. Pharm. Biopharm. 2014, 88, 169-177. [CrossRef]

142. Yang, J.; Ju, Z.; Dong, S. Cisplatin and paclitaxel co-delivered by folate-decorated lipid carriers for the treatment of head and neck cancer. Drug Deliv. 2017, 241, 792-799. [CrossRef] [PubMed]

143. Zhang, J.; Xiao, X.; Zhu, J.; Gao, Z.; Lai, X.; Zhu, X.; Mao, G. Lactoferrin- and RGD-comodified, temozolomide and vincristine-coloaded nanostructured lipid carriers for gliomatosis cerebri combination therapy. Int. J. Nanomed. 2018, 13, 3039-3051. [CrossRef] [PubMed]

144. Liang, Y.; Tian, B.; Zhang, J.; Li, K.; Wang, L.; Han, J.; Wu, Z. Tumor-targeted polymeric nanostructured lipid carriers with precise ratiometric control over dual-drug loading for combination therapy in non-small-cell lung cancer. Int. J. Nanomed. 2017, 12, 1699-1715. [CrossRef] [PubMed]

145. Doktorovová, S.; Kovačević, A.B.; Garcia, M.L.; Souto, E.B. Preclinical safety of solid lipid nanoparticles and nanostructured lipid carriers: Current evidence from in vitro and in vivo evaluation. Eur. J. Pharm. Biopharm. 2016, 108, 235-252. [CrossRef]

146. Akanda, M.H.; Rai, R.; Slipper, I.J.; Chowdhry, B.Z.; Lamprou, D.; Getti, G.; Douroumis, D. Delivery of retinoic acid to LNCap human prostate cancer cells using solid lipid nanoparticles. Int. J. Pharm. 2015, 493, 161-171. [CrossRef]

147. Almeida, H.; Lobão, P.; Frigerio, C.; Fonseca, J.; Silva, R.; Sousa Lobo, J.M.; Amaral, M.H. Preparation, characterization and biocompatibility studies of thermoresponsive eyedrops based on the combination of nanostructured lipid carriers (NLC) and the polymer Pluronic F-127 for controlled delivery of ibuprofen. Pharm. Dev. Technol. 2017, 22, 336-349. [CrossRef]

148. Hwang, T.-L.; Aljuffali, I.A.; Hung, C.-F.; Chen, C.-H.; Fang, J.-Y. The impact of cationic solid lipid nanoparticles on human neutrophil activation and formation of neutrophil extracellular traps (NETs). Chem. Biol. Interact. 2015, 235, 106-114. [CrossRef]

149. Hwang, T.-L.; Aljuffali, I.A.; Lin, C.-F.; Chang, Y.-T.; Fang, J.-Y. Cationic additives in nanosystems activate cytotoxicity and inflammatory response of human neutrophils: Lipid nanoparticles versus polymeric nanoparticles. Int. J. Nanomed. 2015, 10, 371-385.

150. Müller, R.H.; Rühl, D.; Runge, S.; Schulze-Forster, K.; Mehnert, W. Cytotoxicity of solid lipid nanoparticles as a function of the lipid matrix and the surfactant. Pharm. Res. 1997, 14, 458-462. [CrossRef] 
151. Schubert, M.A.; Müller-Goymann, C.C. Characterisation of surface-modified solid lipid nanoparticles (SLN): Influence of lecithin and nonionic emulsifier. Eur. J. Pharm. Biopharm. 2005, 61, 77-86. [CrossRef]

152. Brugè, F.; Damiani, E.; Puglia, C.; Offerta, A.; Armeni, T.; Littarru, G.P.; Tiano, L. Nanostructured lipid carriers loaded with CoQ10: Effect on human dermal fibroblasts under normal and UVA-mediated oxidative conditions. Int. J. Pharm. 2013, 455, 348-356. [CrossRef]

153. Lakkadwala, S.; Nguyen, S.; Lawrence, J.; Nauli, S.M.; Nesamony, J. Physico-chemical characterisation, cytotoxic activity, and biocompatibility studies of tamoxifen-loaded solid lipid nanoparticles prepared via a temperature-modulated solidification method. J. Microencapsul. 2014, 31, 590-599. [CrossRef] [PubMed]

154. Doktorovova, S.; Souto, E.B.; Silva, A.M. Nanotoxicology applied to solid lipid nanoparticles and nanostructured lipid carriers-A systematic review of in vitro data. Eur. J. Pharm. Biopharm. 2014, 87, 1-18. [CrossRef] [PubMed]

155. Kyadarkunte, A.Y.; Patole, M.S.; Pokharkar, V.B. Cellular interactions and photoprotective effects of idebenone-loaded nanostructured lipid carriers stabilized using PEG-free surfactant. Int. J. Pharm. 2015, 479, 77-87. [CrossRef]

156. Vallianou, N.G.; Evangelopoulos, A.; Schizas, N.; Kazazis, C. Potential anticancer properties and mechanisms of action of curcumin. Anticancer Res. 2015, 35, 645-651.

157. Del Pozo-Rodríguez, A.; Delgado, D.; Gascón, A.R.; Solinís, M.Á. Lipid nanoparticles as drug/gene delivery systems to the retina. J. Ocul. Pharmacol. Ther. 2013, 29, 173-188. [CrossRef]

158. Rao, M.P.; Manjunath, K.; Bhagawati, S.T.; Thippeswami, B.S. Bixin loaded solid lipid nanoparticles for enhanced hepatoprotection-Preparation, characterisation and in vivo evaluation. Int. J. Pharm. 2014, 473, 485-492. [CrossRef]

159. Kasongo, K.W.; Pardeike, J.; Müller, R.H.; Walker, R.B. Selection and characterization of suitable lipid excipients for use in the manufacture of didanosine-loaded solid lipid nanoparticles and nanostructured lipid carriers. J. Pharm. Sci. 2011, 100, 5185-5196. [CrossRef]

160. Han, Y.; Li, Y.; Zhang, P.; Sun, J.; Li, X.; Sun, X.; Kong, F. Nanostructured lipid carriers as novel drug delivery system for lung cancer gene therapy. Pharm. Dev. Technol. 2016, 21, 277-281. [CrossRef]

161. Wang, H.; Liu, S.; Jia, L.; Chu, F.; Zhou, Y.; He, Z.; Guo, M.; Chen, C.; Xu, L. Nanostructured lipid carriers for MicroRNA delivery in tumor gene therapy. Cancer Cell Int. 2018, 18, 101. [CrossRef]

(C) 2020 by the authors. Licensee MDPI, Basel, Switzerland. This article is an open access article distributed under the terms and conditions of the Creative Commons Attribution (CC BY) license (http://creativecommons.org/licenses/by/4.0/). 